\title{
EFFECTS OF MATERNAL DEPRESSION ON FAMILY FOOD INSECURITY
}

\author{
$\underline{\text { Abstract }}$ \\ We use data from the Early Childhood Longitudinal Study-Birth Cohort to estimate the \\ effects of maternal depression, a condition that is fairly common and can be severe, on food \\ insecurity, a hardship that has increased substantially in the U.S. Using various model \\ specifications, we find convincing evidence that severe maternal depression increases the \\ likelihood that young children experience food insecurity by $23-69 \%$, with estimates depending \\ on model specification and measures of depression and food insecurity. For household food \\ insecurity, the corresponding estimates are 11-79\%. We also find that maternal mental illness \\ increases reliance on several types of public programs, suggesting that the programs play a \\ buffering role.
}

JEL Codes: H53, I1 ,I3

Key Words: maternal depression, food insecurity, hardship, family well-being 


\section{Introduction}

Food insecurity has increased substantially in the U.S. since the new millennium and the reasons for this trend have not been established. In 2000, $10.5 \%$ of U.S. households were food insecure (defined by the U.S. Department of Agriculture [USDA] as not having consistent access to enough food for active, healthy lives for all members) during the past year; that figure increased to $14.0 \%$ in 2014 (Coleman-Jensen, et al., 2015). Among U.S. households with children in 2014, 9.4\% included at least one child who experienced food insecurity (defined by the USDA as having their food intake reduced and their normal eating patterns disrupted because the household lacked money and other resources for food) (Coleman-Jensen, et al., 2015). Income is a strong correlate of food insecurity, although many poor families do not experience food insecurity and some non-poor families are food insecure (Rose, 1999; Gundersen \& Gruber, 2001).

Theoretical work by Gundersen and Gruber (2001) suggests that adverse life events, such as income or health shocks, can be important determinants of food insecurity, and according to Gundersen, Kreider, and Pepper (2011), “(r)esearch on the impact of health care limitations on food insecurity would be of interest, especially when the causal direction is mixed, both in terms of improved estimates of the impact of food insecurity and in terms of further delineating the causes of food insecurity (p. 298)." We address a closely related issue by estimating the effects of maternal depression, a condition that is fairly common and can be severe but is treatable, on child and family food insecurity.

Using nationally representative data from the Early Childhood Longitudinal Study_Birth Cohort, we estimate effects of maternal depression on measures of child and family food insecurity from the USDA Core Food Security Module (described later), exploiting the panel 
data in several ways. First, we estimate effects of maternal depression on subsequent food insecurity, controlling for food insecurity and other covariates measured in the initial period. Second, we estimate fixed effects models based on repeat observations at three different time points. Third, we estimate effects specifically of maternal depression during the postpartum year, which may include cases of postpartum depression that may be more unexpected than depression after the postpartum year, on subsequent food insecurity, controlling for the maternal grandmother's history of depressive symptoms and other factors measured at or before the birth of the child. For the analyses focusing on maternal depression during the postpartum year, we also estimate two-stage models that use identifiers for depression in that time period that are plausibly exogenous. After comprehensively analyzing the effects of maternal depression on food insecurity using these three approaches, we explore potential buffering effects of the Supplemental Nutrition Assistance Program (SNAP); the Supplemental Nutrition Program for Women, Infants, and Children (WIC); Medicaid; Supplemental Security Income (SSI); and Temporary Assistance to Needy Families (TANF) using similar methods.

\section{Background}

\section{Food security as a social problem}

Food insecurity, a hardship experienced by millions in the U.S., is an important indicator of well-being. Both children and adults living in food insecure households are at increased risk for physical health problems such as asthma and anemia, mental and behavioral problems, and poor educational outcomes (Gundersen, Kreider, \& Pepper, 2011). However, few studies provide strong evidence of causal effects. Using sophisticated nonparametric bounding methods, Gundersen and Kreider (2009) found evidence that food insecurity has adverse effects on children's obesity and general health status, and inferred that previous estimates of adverse 
effects of food insecurity on health are downward biased.

\section{Causes of food insecurity}

Economic theory points to the importance of income as an important determinant of food security (Gundersen \& Gruber, 2001). Research has found that SNAP and other programs are partial buffers against food insecurity, although endogeneity and measurement error represent persistent challenges in studies on the topic that few have been able to satisfactorily address (exceptions are Gundersen \& Kreider, 2008 and Gundersen \& Ribar, 2011). In fact, most studies find positive associations between program participation and food insecurity, which clearly are biased.

Health shocks have been found to affect economic outcomes, and as such, could lead to food insecurity. This literature has generally focused on the elderly (e.g., Smith, 1999; Rosen \& $\mathrm{Wu}, 2004)$. Very few studies have investigated the effects of health shocks on economic outcomes at younger ages, when there may be less financial buffer to overcome the expenses and potential loss in income resulting from health shocks. Exceptions from the U.S. found that health shocks to pre-retirement age married adults have strong negative effects on household wealth (Wu, 2003), poor health significantly increases financial strain in households (Lyons \& Yilmazer, 2005), and that family health shocks reduce parents' labor supply (Corman, Noonan, \& Reichman; Noonan, Reichman, \& Corman, 2005) and increase homelessness (Curtis et al., 2010, 2013, 2014), which is strongly associated with food insecurity (Gundersen et al., 2003).

Despite the potential importance of health shocks as determinants of food insecurity, we know of only one study directly focusing on the topic. Corman, Noonan and Reichman (2014) found no associations between severe infant health shocks and family food insecurity, but that public assistance programs - particularly cash assistance for low-income individuals with 
disabilities—appeared to be important buffers.

\section{The importance of mental health}

In the 2009 Behavioral Risk Factor Surveillance System, 1/3 of individuals answered at least "1" to the question, "...Now thinking about your mental health, which includes stress, depression, and problems with emotions, for how many days during the past 30 days was your mental health not good?" (CDC, 2010). In addition, more than one in thirteen individuals $12+$ years old in the U.S. experienced depression in the past two weeks (in 2009-2012), with women more likely to experience depression than men and working-aged adults more likely to experience depression than children or senior citizens (Pratt \& Brody, 2014).

According to Almlund et al. (2011), non-cognitive traits are as important as cognitive ability in determining economic success, and according to Layard (2013), mental health is an understudied form of human capital despite evidence that it is a major factor affecting productivity and well-being. Studies using a variety of datasets that include different measures of depression have found that mental health disorders, including depression, reduce the likelihood that women are in the labor force and that they are employed (Ettner, Frank, \& Kessler, 1997; Marcotte, Wilcox-Gok, \& Redmon, 2000; Ojeda et al., 2010; Chatterji, Alegria, \& Takeuchi, 2011; Tefft, 2012; Banerjee, Chatterji, \& Lahiri, 2013; Frijters, Johnston, \& Shields, 2014). Other studies using a variety of datasets and measures of depression found that employed individuals with mental illness are more likely to lose their jobs (Nelson and Kim, 2011), that women with depression have lower earnings, that the earnings penalty from depression is larger for those with lower incomes (Marcotte, Wilcox-Gok, and Redmon, 2000; Marcotte and WilcoxGok, 2003), and that although depressed individuals have lower wages than their non-depressed peers, changes in depression status do not correspond to wage changes (Cseh, 2008). Berndt et 
al. (1998), using data from a clinical trial, found evidence of improvements in self-perceived productivity as depressive symptoms were reduced, suggesting that depression negatively affects productivity on the job.

While the above studies investigated the effects of mental health on labor market outcomes (and, by inference, earned income) and had findings that were quite consistent in terms of direction of estimated effects, few studies have investigated effects of mental health on household production, decision-making, or material hardship.

\section{Mental health and food insecurity}

Siefert et al. (2000), Carter et al. (2011), Heflin, Siefert, and Williams (2005), Casey et al. (2004) and others found positive associations between mental illness and food insecurity, again using different datasets with different depression measures. Unlike the recent literature on mental health and labor market outcomes described above, these studies did not attempt to model causality or address potential endogeneity. One exception (Heflin \& Ziliak, 2008) used an individual fixed effects approach and found some evidence that food insufficiency causes emotional distress. Recently, Garg et al. (2015), using data from the Early Childhood Longitudinal Study_-Birth cohort, the same dataset used for the current study, found that depression in mothers with 9 month old children was associated with $50 \%$ higher odds of household food insecurity 15 months later. The sample was restricted to women with household incomes below $185 \%$ of the poverty level when their children were 9 months old; since depression affects women's labor market outcomes, some women may have been included in the sample because they experienced depression, potentially biasing the results. The authors did not consider food insecurity at the initial point, leaving open the possibility that the observed associations reflect reverse causality (from food insecurity to depression). Finally, the authors 
did not employ any statistical techniques to account for potential confounding by unobserved factors; as such, the associations could be biased or even spurious.

Dahal and Fertig (2013) estimated effects of mental illness on spending behavior and found that women with mental health problems spend more on a variety of consumer goods, but less on investments such as education — a phenomenon they attributed to "retail therapy." For low-income households, this scenario might result in not being able to afford food at some point in the budget cycle.

We know of no studies that have explicitly attempted to estimate effects of mental illness on food insecurity that are causal, despite evidence that the two are correlated, that depression reduces labor force participation, that depression appears to lower productivity on the job (and, by extension, potentially also in the household), and that mental illness affects women's spending patterns. We address this gap by attempting to estimate causal effects of maternal depression on child and family food insecurity. The hypothesized channels, which we do not test in this study, are decreases in labor supply and decreases in expenditures on high quality food, with the former reflecting income effects and the latter reflecting income effects or budget allocation decisions.

\section{Data}

The Early Childhood Longitudinal Study_Birth Cohort (ECLS-B) is a nationally representative panel study of $>10,000$ children born in the U.S. in 2001. Births were sampled from Vital Statistics natality records and consist of children born in 2001 who were alive at 9 months, had not been placed for adoption, and were born to mothers aged >=15 years old (Bethel et al., 2005). Twins, low birthweight infants, and American Indian/Alaskan Natives and Asian/Pacific Islander mothers were oversampled. The initial (baseline) survey was conducted 
when the child was 9 months old, and follow-up surveys were completed at 2, 4, and 5 years (the 5-year follow-up data are not used in our study). Additionally, the ECLS-B includes data on maternal and infant health and some demographic factors from the infants' birth records. All sample sizes are rounded to the nearest 50 as required by the National Center for Education Statistics.

The ECLS-B is highly appropriate for studying the effects of maternal depression on child and household food insecurity because it: (1) is a nationally representative, panel dataset with a large sample; (2) includes information on maternal depression and household food insecurity collected using widely-used standardized instruments; (3) allows us to measure both maternal depression and food insecurity at multiple time points; (4) includes a rich set of relevant control variables, including the maternal grandmother's history of depression; (5) includes state indicators, allowing us to control for potentially confounding factors at the state level; and (6) includes information on participation in a number of relevant public assistance programs at each survey wave.

As discussed earlier, few existing studies have isolated causal relationships between physical or mental health and food insecurity, in either direction. We take an important step in addressing this gap by estimating effects of maternal depression on food insecurity using a number of different model specifications, each of which has unique strengths and limitations in addressing the two key methodological challenges — omitted variables bias and reverse causality — but, together, paint a remarkably consistent picture. After undertaking a comprehensive analysis of effects of maternal depression on food insecurity, we explore the potential buffering effects of the SNAP, WIC, Medicaid, SSI, and TANF. We model participation in each program as a function of maternal depression using essentially the same 
methodological approaches used to predict food insecurity, and make inferences based upon those results. All supplementary results identified as "not shown" are available from the authors upon request.

First, we estimate multivariate probit models of the effects of maternal depression (assessed at 2 years) on food insecurity (assessed at 4 years), controlling for a rich set of covariates including food insecurity assessed at 2 years. We consider a number of different model specifications in order to assess robustness and patterns. These models estimate associations between maternal depression and subsequent food insecurity in families, controlling for their food insecurity in the initial period. Because these models allow us to clearly establish the temporal ordering of events, reverse causality is not a concern. However, these models rely on our controls for observed characteristics to account for differences between mothers with and without depression.

Second, we estimate linear fixed effects regression models that control for time-varying covariates and which implicitly control for all time-invariant characteristics of households. These models allow us to investigate the extent to which changes in depression are associated with changes in food insecurity in families - an even more stringent specification than that outlined above_-but do not address potential reverse causality.

Third, we exploit a specific mental health event—maternal depression during the postpartum year-which is thought to have at least some random component. According to O’Hara and Swain (1996), postpartum depression (which is related to, but not the same as, maternal depression during the postpartum year) is unrelated to many sociodemographic characteristics, and therefore may be more likely than depression at subsequent time points to come as an unexpected event. For these analyses, we estimate multivariate probit models of the 
effects of maternal depression during the postpartum year (assessed at 9 months) on food insecurity (assessed at 2 years), controlling for a host of potentially confounding variables. To the extent to which we have truly captured random health shocks, this set of models would account for both unobserved heterogeneity and reverse causality.

To further address potential unobserved heterogeneity in the analyses focusing on the effects of maternal depression during the postpartum year, we also estimate 2 -stage models that identify depression during the postpartum year using multiple births (oversampled in the ECLSB) and serious infant health conditions. Previous research found that multiples births are associated with maternal depression during the postpartum year (Choi, Bishai, \& Minkovitz, 2009) and that mothers of very low birthweight infants with bronchopulmonary dysplasia reported more postpartum psychological distress than mothers of term infants (Singer et al., 1999). Our measure of infant health encompasses a range of conditions. Prior research identified infant health conditions that are considered by the medical community to be largely random (e.g., Down Syndrome, congenital heart malformations), given that the pregnancy resulted in a live birth (Curtis et al., 2013). We used information from the birth certificate module of the ECLS-B to code whether the infant had such a condition. These models control for food insecurity at the initial period ( 9 months) and therefore account for reverse causality.

The three sets of models described above are based on three somewhat different analysis samples. In each case, we start with 10,450 participants in the ECLS-B, all of whom had birth certificate data, and impose varying specific sample restrictions to generate the analysis samples. Note that all sample sizes are rounded to the nearest 50, as required by our data agreement.

For the models of the effects of maternal depression at 2 years on food insecurity at 4 years, we limit the sample to the 8,750 cases for which the mother completed a 4-year interview. 
Of those, 150 were dropped because the mother was not interviewed at 2 years, an additional 50 were dropped because of missing information on food insecurity, and another 400 were dropped due to missing information on depression or other analysis variables. We refer to the resulting sample of 8,150 cases as "Sample A."

The fixed effects models were based on all mothers who participated in at least two waves of the survey and for whom there was non-missing data on all analysis variables in the waves in which they participated, resulting in a total of 24,700 observations of 9,100 different mothers. We refer to the fixed effects sample as "Sample B."

For the models of the effects of maternal depression during the postpartum year on food insecurity at 2 years, we limit the sample to the 9,600 cases with 2-year follow-up data. Of those, 1,500 were dropped owing to missing data on maternal depression and another 300 were dropped because they had missing data on food insecurity or other analysis variables, leaving an analysis sample of 7,800 cases, which we refer to as "Sample C."

The 3 different analysis samples are very similar on all characteristics, making us comfortable comparing results across the corresponding model specifications. Comparing mothers included in our analyses to those not included (for Sample A and Sample C), we found that the former were less likely to be non-Hispanic black, Hispanic, Asian, foreign born, and have a Medicaid birth, and more likely to be employed and to be married (results not shown). The under-representation of socioeconomically disadvantaged mothers may result in downward biased estimates of the effects of maternal depression on food insecurity.

\section{Measures and descriptive analysis}

Characteristics of the three different analysis samples are presented in Table 1. For each sample, summary statistics are presented for characteristics that are included in models using that 
sample, with two exceptions: Maternal baseline characteristics and 9-month other family member characteristics are presented for Sample B even though they are not included in the fixed effects models, so the reader can compare compositional characteristics across the three samples. Program participation variables are not included in models of food insecurity; instead, program participation is examined in a separate set of models based on Samples A and B that correspond largely to the analyses of food insecurity based on those samples. The decision to investigate the potential role of program participation this way, instead of explicitly modeling it in conjunction with food insecurity, is based on the pervasive methodological challenge of accounting for selection into program participation discussed earlier. Gundersen, Kreider, and Pepper (2011) cite a few studies that have been able to overcome this challenge and found beneficial effects of program participation on food security. However, we are unable to implement those same methods with our data.

We consider two different measures of food insecurity at three different time points— -9 months, 2 years and 4 years - based on the USDA Core Food Security Module that is embedded in the mother's interviews (see Appendix Table 1 for a list of the questions in the module and Coleman-Jensen et al., 2013 for a full description of the module and measures). The USDA Core Food Security Module consists of 18 questions about food hardship during the past year, which we use to create measures of child and household food insecurity. Per USDA definitions, children are considered to have very low food security if the mother gave affirmative responses to $5+$ of the 8 questions pertaining to children, and low food security if the mother gave affirmative responses to 2, 3 or 4 of the 8 questions. Owing to small sample sizes and consistent with USDA methodology, we combine these two categories and refer to families meeting these criteria as having experienced child food insecurity. Also per USDA definitions, households are 
considered food insecure if the mother responded affirmatively to $3+$ of the 18 questions in the Core Food Security Module (6+ denotes very low food security). At 9 months, about $5 \%$ of families had experienced child food insecurity within the past year and $12 \%$ had experienced household food insecurity. The corresponding rates were 4 and $8-9 \%$ at 2 years and 7 and $12 \%$ at 4 years.

These figures are lower than the national figures from Nord, Andrews, and Carlson (2004) indicating that $\sim 17 \%$ of households with children in 2003 had low or very low food insecurity. However, according to Snow et al. (2009), households with very young children (as in the ECLS-B) have lower levels of food insecurity than households with older children.

Maternal depression was assessed at 9 months, 2 years, and 4 years. At 9 months and 4 years, depression was assessed in the ECLS-B using an abbreviated form of the Center for Epidemiological Studies Depression Scale (CES-D) that assesses depressed affect, positive affect, somatic symptoms, psychomotor retardation, and interpersonal activity (Radloff, 1977). The instrument contains 12 items describing symptoms; each item is coded on a 4-point scale between 0 and 3, for the symptom occurring never (a score of zero), 1-2 days (score of 1), 3-4 days (score of 2), or 5-7 days (score of 3) during the past week, with total scores ranging from 0-36. Using established cutoff scores provided by the ECLS-B, a score >=15 or more suggests severe depression and a score $>=10$ suggests moderate or severe depression. We use the former as our primary measure of depression, but perform supplementary analyses using the broader measure. At 9 months, about $7 \%$ of the mothers are characterized as having experienced severe depression during the past week and $18 \%$ are characterized as having experienced moderate or severe depression during the past week. At 4 years, the rates were similar to those at 9 months, 7 and $20 \%$, respectively. 
At 2 years, depression was assessed in the ECLS-B using the Composite International Diagnostic Interview Short Form (CIDI-SF), which was embedded in the 2-year survey. The CIDI is a comprehensive, fully-structured interview designed to be used by trained lay interviewers for the assessment of mental disorders according to the definitions and criteria of ICD-10 and DSM-IV (and earlier versions, as relevant). The CIDI-SF was developed for use in the U.S. National Health Interview Survey. Kessler et al. (1998) found that it is an accurate proxy for the full CIDI instrument; however, they did not conduct a broad population-based validation study. The 2-year mother survey in the ECLS-B contained all of the CIDI-SF questions to allow us to score both a major depressive episode and a moderate to severe depressive episode using established cutoffs. The scoring was based on documentation for the Fragile Families and Wellbeing Survey 1-year questionnaire, which had identical questions to those in the 2-year ECLS-B mother survey (Princeton University, 2012).

Our main measure of depression using the CIDI-SF, a dichotomous indicator for whether the mother met the diagnostic criteria for major depression since the last interview (in the past 15 months), is based on a count of number of depressive symptoms ranging from 0 to 7 , with a major depressive episode defined as the experience of 3 or more symptoms of dysphoria or anhedonia for most of the day for a period of at least 2 weeks. The symptoms include being sad, being blue, and losing interest in things. About $8 \%$ of the mothers in our sample experienced depression in the 15 months prior to their 2-year interviews based on this measure. We assess sensitivity to a broader established measure characterizing respondents who reported experiencing symptoms for at least half the day (instead of most of the day) for a period of at least 2 weeks in the 15 months prior to their 2-year interviews. Approximately, $10 \%$ of mothers 
in our sample are characterized as having experienced depression in the 15 months prior to their 2-year interviews based on this more inclusive measure.

For both CIDI- SF (2 years) and CES-D ( 9 months and 4 years), the more severe measure is our preferred measure, both because it represents a more extreme "treatment" and because the rates of severe depression are much more similar across the 9-month, 2-year, and 4-year surveys than are those of moderate or severe depression. Overall, $12 \%$ of mothers experienced severe depression at 1 of the 3 survey waves, $3 \%$ experienced severe depression at 2 of the survey waves, and .6\% experienced severe depression at all three waves. The corresponding figures for moderate or severe depression were $21 \%, 8 \%$ and $2 \%$, respectively (not shown).

Among the past studies on the effects of maternal depression discussed earlier, those that used either the CIDI or CES-D were Banerjee, Chatterji \& Lahiri (2013), Chatterji, Alegria \& Takeuchi (2011), Marcotte, Wilcox-Gok, and Redmon, 2000 (2000), and Ettner, Frank \& Kessler (1997), which used the CIDI to estimate effects of women's depression on labor supply; Siefert et al. (2000) and Heflin, Siefert \& Williams (2005), which used the CIDI to investigate effects of maternal depression on food insecurity; Cseh (2008) which used the CES-D to estimate effects of depression on men's and women's wages; and Garg (2015), which the used the CES-D to estimate associations between maternal depression and young children's food insecurity.

Regarding our models that focus on effects of depression during the postpartum year, it should be noted that the measures of maternal depression at 9 months based on the CES-D do not capture postpartum depression per se (which is generally based on the first 6 months after childbirth) or an actual diagnosis. Rather, these measures characterize maternal depression at a specific point during the postpartum year based on one of a number of different instruments that 
are used to assess postpartum depression from surveys. According to a recent review article about the course of postpartum depression, the 0-6 month time interval typically used to assess postpartum depression may be overly rigid, as 30-50\% of mothers with postpartum depression continue to have major depression during their child's first year (Vliegen, Casalin, \& Luyten, 2014). As such, our measures of maternal depression during the postpartum year likely capture many cases of conventionally-defined postpartum depression, which is an unexpected event for many mothers (O’Hara \& Swain, 1996). However, because our measures of maternal depression at 9 months do not conform to the 0-6 month period after childbirth, we refrain from referring to our CES-D-based measures as postpartum depression. Rather, we refer to these measures as maternal depression or depression during the postpartum year.

In all models other than fixed effects regressions, which implicitly control for timeinvariant maternal characteristics, we include the following characteristics of the mother (measured at or before the time of the birth): age, race/ethnicity, nativity, Medicaid birth, and whether the mother lived with both of her own parents at age 16. We also include whether the maternal grandmother had a history of depressive symptoms and the child's father's education, both reported at 9 months. Six to seven percent of the mothers in the sample had a mother with a history of depressive symptoms. This measure is intended to capture the mother's family-related (genetic or environmental) predisposition for depression. These models also include a control for the corresponding measure of food insecurity in the initial wave (when depression was measured). In most specifications, we include indicators for the mother's state of residence at 9 months.

In the fixed effects models (which use Sample B), we include all of the time-varying characteristics in Table 1, measured at 9 months, 2 years, and 4 years: maternal education, 
marital status, cohabitation status, number of children under age 18 years in the household, number of adults in the household, full- and part-time employment (both compared to not employed), household income (in \$'s and divided by 10,000 with all significant digits preserved), living in an urban area and living in an urban cluster (both compared to living in a non-urban area), and self-reported health status (excellent, good or very good, versus fair or poor). Urban area refers to a densely populated urban area and urban cluster refers to a less densely populated urban area, as classified by the ECLS-B based on U.S. Census categories.

When estimating food insecurity at 4 years as a function of maternal depression at 2 years (using Sample A), we include the characteristics classified in Table 1 as time-varying, but measured only at 2 years (education, marital and cohabitation status, household composition, employment, income, urban residence variables, and maternal health). Using the 2-year measures controls for these factors in the initial period in these analyses, whereas the measure of maternal depression at 2 years pertains to the past year. To the extent that the mother's marital and cohabitation status, household composition, employment, income urban residence, and health lie along the causal pathway from maternal depression to food insecurity, including these factors in the models may lead to overly conservative estimated effects of maternal depression on food insecurity. Thus, as a specification check, we also estimate models using 9-month measures of these variables, which clearly precede the reports of maternal depression, instead of the 2-year measures (results not shown).

When estimating food insecurity at 2 years as a function of maternal depression at 9 months (Sample C), we include the number of children in the household, the number of adults in the household, household income, and the urban area and urban cluster variables, all measured at 9 months, as well as maternal education at the time of the birth, marital and cohabitation status 
at the time of the birth, maternal employment in the year prior to the birth of the child, and whether the mother had any prenatal health condition. In these models, all of the control variables would ideally be measured at the time of the birth (pre-depression) in order to preserve the temporal ordering of events and allow depression during the postpartum year to have effects on food insecurity through any and all channels. However, the household composition, income, and urban residence variables are not available in the ECLS-B until 9 months. Information on marital status and prenatal health conditions is from the birth certificate module, and it was possible to characterize cohabitation and maternal employment at the time of the birth from information provided by the mother at 9 months.

Overall, mothers who had depression were younger, less educated, less likely to be foreign born, less likely to be married, more likely to be cohabiting, less likely to have lived with both parents at age 16, and more likely to have had births covered by Medicaid than mothers who did not have depression (not shown). This is the case even for maternal depression at 9 months, which stands in contrast to the relevant literature which found that postpartum depression is unrelated to most demographic characteristics (O'Hara and Swain, 1996). This systematic pattern of less advantaged mothers being more likely to experience depression underscores the importance of addressing the potential endogeneity of maternal depression. As expected, the maternal grandmother's history of depression is strongly associated with maternal depression (not shown). Finally, mothers who were depressed at 9 months were less likely to have participated in the subsequent surveys than mothers who were not depressed at 9 months, potentially resulting in underestimated effects of maternal depression on food insecurity (not shown).

\section{Multivariate Analysis}


The main results from the three sets of analyses for food insecurity described earlier are presented in Tables 2-4, and those for the analyses of program participation are presented in Table 5.

\section{4-year food insecurity as a function of 2-year maternal depression: Sample A}

For each of the food insecurity outcomes and measures of maternal depression at 2 years described earlier, we present the estimated effects of maternal depression from five different probit models (Table 2). Model 1 includes no covariates. Model 2 includes all baseline and "other family member" characteristics at 9 months, as well as 2-year characteristics classified as time-varying for which means are shown in the first column of Table 1 (Sample A). Model 3 is the same as Model 2 but also includes indicators for the mother's state of residence at 9 months. Model 4 is same as Model 3 but also includes food insecurity at 9 months, using the measure of food insecurity that corresponds to the outcome. Model 5 is the same as Model 3 but also includes food insecurity at 2 years (using the measure of food insecurity that corresponds to the outcome).

In all but one model (that estimated the effect of severe depression on household food insecurity, controlling for baseline maternal and 9-month other family member characteristics, time-varying characteristics measured at 2 years, and food insecurity at 2 years), maternal depression significantly increases the likelihood of subsequent food insecurity. The estimated effects of depression generally decline as covariates are added, with the largest declines between Models 1 and 2. The inclusion of food insecurity at either 9 months or 2 years further decreases the estimated effect of maternal depression. After controlling for many observed factors and food insecurity at either 9 months or 2 years, severe depression increases the probability of child food insecurity by $23-29 \%$ and the probability of household food insecurity by $11-18 \%$, relative to the 
relevant sample means. When controlling for 9-month, rather than 2-year, characteristics classified in Table 1 as time-varying, the results are very similar (not shown).

Full probit results (other than the estimates for the state indicators) from Model 4, which controls for food insecurity in the previous period (and is therefore our preferred model) in Table 2, using the severe measure of maternal depression, are presented in Appendix Table 2. Full sets of estimates from the other models in Table 2 are not shown, but tend to be very similar. Families with mothers who were married or cohabiting, had any college education, had higher household income, and had favorable health status were significantly less likely than their more socioeconomically disadvantaged counterparts to experience food insecurity, as were families in which the father had some college education. Those whose mothers had a history of depressive symptoms, had Medicaid-financed births, and experienced food insecurity at 2 years were significantly more likely to experience food insecurity at 4 years.

\section{Fixed effects models: Sample B}

Regardless of which measures of maternal depression and food insecurity are considered, results from the family fixed effects models indicate that maternal depression is significantly associated with contemporaneous food insecurity (Table 3). These models implicitly control for all time-invariant characteristics and explicitly control for time-varying characteristics of families. As discussed earlier, these models have an advantage over the previous models in terms of addressing unobserved heterogeneity. However, they do not allow us to clearly establish the temporal ordering of events, and as such, may reflect reverse causality. The magnitudes of the estimated effects are large, with severe maternal depression increasing the likelihood of child food insecurity by $79 \%$ and household food insecurity by $69 \%$, compared to the corresponding mean values over the three observations in this set of models. As in Appendix Table 2, the 
number of adults in the household significantly decreases the probability of both child and household food insecurity while the number of children in the household is positively associated with child food insecurity. Having a cohabiting partner and higher household income are significantly associated with lower levels of child and household food insecurity. 2-year food insecurity as a function of maternal depression during postpartum year (9 months): Sample C

For each of the food insecurity outcomes and measures of maternal depression during the postpartum year, we present the estimated effects of maternal depression from four different probit models (Table 4). Model 1 includes no covariates. Model 2 includes all maternal baseline and 9-month other family characteristics shown in the third column of Table 1 (Sample C), and state of residence indicators from the 9-month survey. Model 3 is the same as Model 2 but also includes 9-month characteristics classified as time-varying for which means are shown in the third column of Table 1 (Sample C). Maternal education, marital status, cohabitation status, employment, and physical health status at 9 months are not included in these models; we use baseline measures of those characteristics instead to preserve the temporal ordering from these control variables to the episode of maternal depression (measured at 9 months) to food insecurity status (measured at 2 years). Model 4 is the same as Model 3 but also includes 9-month food insecurity that corresponds to the outcome. Full probit results (other than the estimates for the state identifiers) for Model 4 from Table 4, using the measure of severe depression for each of the two measures of food insecurity, are presented in Appendix Table 3. Full sets of estimates from all of the other models in Table 4 are similar.

In all models, maternal depression during the postpartum year significantly increases the likelihood of both child and household food insecurity. The marginal effects generally decline as 
covariates are added, with the largest declines between Models 1 and 2. The inclusion of food insecurity at 9 months further reduces the estimated effects of depression. For both child and household food insecurity, the estimates are uniformly higher when using the more stringent measure of maternal depression, suggesting a dose-response association that was not apparent in similar models when the child was two years older, which were based on a different depression screener (Table 2). Again, the effect sizes are very large-e.g., in the most adjusted model (Model 4), severe maternal depression increase the likelihood that children will be food insecure by $74 \%$ and increases the likelihood that households will be food insecure by $51 \%$.

To explore the potential endogeneity of maternal depression in this set of models, we estimate 2-stage (bivariate probit) models that use multiple birth and presence of an infant health condition (previously defined) as identifiers for maternal depression. Results from these models, which estimate maternal depression during the postpartum year (using the severe measure) in the first stage and food insecurity in the second stage, for both measures of food insecurity, indicate that: (1) the two identifiers are jointly significant predictors of maternal depression during the postpartum year, (2) the two identifiers are excludable from each outcome equation, and (3) the error term in the maternal depression equation is not significantly correlated with the error term in the outcome equation, for either outcome. These results, which are based on standard statistical tests for two stage models, suggest that our fully-adjusted single-equation estimates of the effects of maternal depression in the postpartum year on food insecurity are not biased. These results are presented in Appendix Table 4. That said, these models represent only one of the many model specifications we used in this study, and are not our preferred specification given the general imprecision of estimates in two-stage models, even when identifiers are considered conceptually and empirically appropriate. Rather, these estimates represent an alternative 
specification that contributes an additional data point to our set of alternative approaches and should not be considered in isolation from the other approaches.

Taken together, the findings from our three sets of analyses consistently suggest that severe maternal depression increases child and family food insecurity, with estimated effects ranging from 23 to $69 \%$ for household food insecurity and 11 to $79 \%$ for child food insecurity after controlling for many observed factors.

\section{Potential buffering effects of public programs}

Having found robust and convincing evidence that maternal depression leads to food insecurity, we explore potential buffering effects of SNAP, WIC, Medicaid, SSI, and TANF. In this set of analyses, we consider that for public assistance to buffer the effects of maternal depression on food insecurity, maternal depression would have to increase program participation, and we explore this question as a "first step" in trying to understand the potential roles that the various public programs play in buffering the effects of maternal depression on child and household food insecurity. The difficulties of explicitly modeling the potential buffering roles of the programs were discussed earlier.

For these analyses, we use Samples A and B along with the corresponding methods. First, we estimate effects of maternal depression (assessed at 2 years and pertaining to the past year) on participation in a given program at 4 years (assessed at 4 years and pertaining to the time since the 2-year interview), controlling for participation in the same program at 2 years (assessed at 2 years and pertaining to the period between the 9- month and 2-year interviews) and the same set of covariates as in Appendix Table 2 aside from the measure of earlier food insecurity. Second, we estimate family fixed effects models that incorporate contemporaneous measures of maternal depression, program participation, and time-varying covariates using data from the 9 month, 2 
year, and 4 year surveys. The estimated effects of maternal depression on participation in the various programs from these two sets of analyses are summarized in Table 5, and the full estimation results are presented in Appendix Tables 5 and 6. Fixed effects models for SSI participation are based on data from 2 and 4 years only, because the 9 -month survey did not ask about SSI.

As for the corresponding models of food insecurity, we view the two sets of analyses of program participation as complementary. The first set of models allows us to clearly establish the temporal ordering of events; as such, reverse causality is not a concern. However, these models rely on our controls for observed characteristics (including the mother's previous program participation) to account for differences between mothers with and without depression. The fixed effects models allow us to investigate the extent to which changes in depression are associated with changes in program participation - a more stringent specification in terms of potential omitted variables bias, but do not address potential reverse causality.

We find that maternal depression at 2 years is significantly and positively associated with participation in TANF at 4 years using both measures of depression, and that moderate or severe depression at 2 years is significantly and positively associated with SSI and SNAP participation at 4 years. The effects of severe depression at 2 years on SNAP and SSI participation at 4 years are positive, but imprecisely estimated. Effect sizes (for severe depression) are approximately $10 \%$ for SNAP, TANF and SSI (considering the marginal effects relative to the relevant program participation means). In this set of models, there are no associations between maternal depression and participation in WIC or Medicaid. We infer from the estimates in Table 5 that families with depressed mothers would have had worse food security outcomes in the absence of SNAP and SSI. 
Estimates from the fixed effects models indicate that severe depression is positively associated with current participation in SNAP and Medicaid, but that moderate or severe depression is positively associated with participation in all programs other than WIC. Severe depression is associated with a $11 \%$ increase in SNAP participation and a $6 \%$ increase in Medicaid; it is also associated with a $11 \%$ increase in SSI, although that estimate is not statistically significant. The across-the-board lack of associations between maternal depression and WIC are not surprising, as that program would be most relevant in the postpartum period, which these models do not capture.

Taken together, the estimates presented in Table 5 suggest that maternal depression increases participation in SNAP - the program that directly targets food insecurity. It also appears to increase participation in SSI, which provide cash assistance (for the former, to individuals with disabilities). We infer from the estimates in Table 5 that participation in SNAP and SSI appear to buffer the effects of maternal depression on food insecurity — that is, that without these supports, families with depressed mothers may have had worse food security outcomes, given previous research establishing that the programs have a positive effect on food security (Gundersen \& Kreider, 2008 and Gundersen \& Ribar, 2011). In general, the associations with program participation are stronger and more significant for moderate or severe depression than for severe maternal depression, suggesting that severe depression may hinder mothers' efforts in navigating the systems required to obtain benefits.

\section{Alternative model specifications}

In additional models (results not shown), we (1) included indicators for depression in one wave only, in two waves, and in all three waves in probit models, (2) used continuous measures of depression in probit and fixed effects models, (3) excluded the 2-year wave that used the 
alternative measure of depression in fixed effects models, and (4) controlled for autocorrelation in the fixed effects models. As expected, in (1) we found a dose-response relationship, wherein the more waves the woman was depressed, the stronger the estimated effects on food insecurity at 4 years. In (2), we found that the findings were in line with those that used cutoffs. In (3), which addressed potential measurement error arising from using a different depression measure at 2 years than at the other waves, the results were not substantively changed, suggesting that our main findings are not biased by the different screener for depression in the 2-year wave. In (4), results from fixed effects models that controlled for autocorrelation but not heteroskedasticity were very similar to those in Table 3 .

\section{Conclusion}

Rates of food insecurity have increased since the millennium, coinciding with the combined forces of the reduced safety net resulting from welfare reform in the 1990s, the Great Recession that began in 2008, and recent cutbacks to SNAP. Using nationally representative data from the ECLS-B and a number of different modeling approaches, we found robust evidence that maternal depression has adverse effects on child and household food insecurity. As far as we know, this study represents the first comprehensive test of the effects of an adverse mental health event on food insecurity. We also found that maternal depression increases the likelihood of participation in SNAP and SSI, and therefore that these programs appear to buffer the effects of health events on food hardship. Future research is needed to complement the findings of this study by investigating the effects of other types of health events (the only existing study of which we are aware, cited earlier, found no associations between poor infant health and food insecurity but that SSI appeared to play a buffering role), as well as the importance of timing of those 
events, on individuals' and family members' food-related hardship at various stages of the life course.

We close with a few caveats. First, despite the robustness of our findings across numerous model specifications, we may not have not fully accounted for all confounding important factors. As such, inferences should be based on ranges and patterns of estimates rather than specific point estimates. Second, it is possible that selective attrition from the longitudinal study (i.e., by maternal depression) biased our estimates. However, unless mental illness decreases food insecurity, the bias should be downward. Third, since data on treatment for depression were not available in our data, we were unable to explore the role of treatment and our estimates are net of any treatment received or not received; that is, to the extent we were successful, we isolated the remaining "problem" that interventions could address. Finally, rigorous research is needed to obtain better estimates of the buffering effects of the various public support programs. 


\section{References}

Almlund, M., Duckworth, A. L., Heckman, J. J., \& Kautz, T. D. (2011). Personality Psychology and Economics. Chapter 1 in Hanushek, E.A., Machin, S. \& Woessmann, L. (eds.) Handbook of the Economics of Education. Volume 4, pp. 1-18.

Banerjee, S., Chatterji, P., \& Lahiri, K. (2013). Effects of Psychiatric Disorders on Labor Market Outcomes: A Latent Variable Approach Using Multiple Clinical Indicators. CESifo Working Paper No. 4260. Accessed on 2/3/14 from: [https://www.econstor.eu/dspace/bitstream/10419/77680/1/cesifo_wp4260.pdf

Berndt, E. R., Finkelstein, S. N., Greenberg, P. E., Howland, R. H., Keith, A., Rush, A. J., ... \& Keller, M. B. (1998). Workplace Performance Effects from Chronic Depression and its Treatment. Journal of Health Economics, 17(5), 511-535.

Bethel, J., Green, J., Kalton, G., et al. (2005). Early Childhood Longitudinal Study, Birth Cohort (ECLS-B), Sampling. Volume 2 of the ECLS-B Methodology Report for the 9-Month Data Collection, 2001-02 (NCES 2005-147). Washington, DC: U.S. Department of Education, National Center for Education Statistics 2005.

Carter, K. N., Kruse, K., Blakely, T., \& Collings, S. (2011). The Association of Food Security with Psychological Distress in New Zealand and Any Gender Differences. Social Science \& Medicine, 72(9), 1463-1471.

Casey, P., Goolsby, S., Berkowitz, C., Frank, D., Cook, J., Cutts, D., Black, M., et al. (2004). Maternal Depression, Changing Public Assistance, Food Security, and Child Health Status. Pediatrics, 113(2), 298-304.

CDC (2010). Behavioral Risk Factor Surveillance System 2009 Codebook Report. http://www.cdc.gov/brfss/annual_data/annual_2009.htm. Accessed 2/5/14.

Chatterji, P., Alegria, M., \& Takeuchi, D. (2011). Psychiatric Disorders and Labor Market Outcomes: Evidence from the National Comorbidity Survey-Replication. Journal of Health Economics, 30(5), 858-868.

Choi, Y., Bishai, D., \& Minkovitz, C.S. (2009). Multiple Births Are a Risk Factor for Postpartum Maternal Depressive Symptoms. Pediatrics, 123(4), 1147-1154.

Coleman-Jensen, A., Rabbitt, M., Gregory, C. \& Singh, A. (2015). Household Food Security in the United States in 2014 (Economic Research Report No. 194). Accessed on 1/24/16 from: http://www.ers.usda.gov/publications/err-economic-research-report/err194.aspx.

Corman, H., Noonan, K., \& Reichman, N.E. (2005). Mothers' Labor Supply in Fragile Families: The Role of Child Health. Eastern Economic Journal, 31(4), 601-616.

Corman, H., Noonan, K., \& Reichman, N.E. (2014). Effects of Infant Health on Family Food Insecurity: Evidence from Two U.S. Birth Cohort Studies. Social Science and Medicine, $123,18-25$.

Cseh, A. (2008). The Effects of Depressive Symptoms on Earnings. Southern Economic Journal, 75(2), 383-409.

Curtis, M., Corman, H., Noonan, K., \& Reichman, N.E. (2010). Effects of Child Health on Housing in the Urban U.S. Social Science and Medicine, 71(12), 2049-2056.

Curtis, M. A., Corman, H., Noonan, K., \& Reichman, N. E. (2013). Life Shocks and Homelessness. Demography, 50(6), 2227-2253.

Curtis, M. A., Corman, H., Noonan, K., \& Reichman, N. E. (2014). Maternal Depression as a Risk Factor for Family Homelessness. American Journal of Public Health, 104(9), 16641670.

Dahal, A., \& Fertig, A. (2013). An Econometric Assessment of the Effect of Mental Illness on 
Household Spending Behavior. Journal of Economic Psychology, 37, 18-33.

Ettner, S. L., Frank, R. G., \& Kessler, R. C. (1997). The Impact of Psychiatric Disorders on Labor Market Outcomes. Industrial and Labor Relations Review, 51(1), 64-81.

Frijters, P., Johnston, D. W., \& Shields, M. A. (2014). The Effect of Mental Health on Employment: Evidence from Australian Panel Data. Health Economics, 23(9), 10581071.

Garg, A., Toy, S., Tripodis, Y., Cook, J., \& Cordella, N. (2015). Influence of Maternal Depression on Household Food Insecurity for Low-Income Families. Academic Pediatrics, 15(3), 305-310.

Gundersen, C., \& Gruber, J. (2001). The Dynamic Determinants of Food Insecurity, in Second Food Security Measurement and Research Conference, Volume II: Papers. Food Assistance and Nutrition Research Report 11-2, pp. 92-110. Margaret Andrews and Mark Prell (eds.), USDA, Economic Research Service.

Gundersen, C., \& Kreider, B. (2008). Food Stamps and Food Insecurity What Can Be Learned in the Presence of Nonclassical Measurement Error? Journal of Human Resources, 43(2), $352-382$.

Gundersen, C., \& Kreider, B. (2009). Bounding the Effects of Food Insecurity on Children's Health Outcomes. Journal of Health Economics, 28(5), 971-983.

Gundersen, C., Kreider, B., \& Pepper, J. (2011). The Economics of Food Insecurity in the United States. Applied Economic Perspectives and Policy, 33(3), 281-303.

Gundersen, C., \& Ribar, D. (2011). Food Insecurity and Insufficiency at Low Levels of Food Expenditures. Review of Income and Wealth, 57(4), 704-726.

Gundersen, C., Weinreb, L., Wehler, C., \& Hosmer, D. (2003). Homelessness and Food Insecurity. Journal of Housing Economics, 12(3), 250-272.

Heflin, C. M., Siefert, K., \& Williams, D. R. (2005). Food Insufficiency and Women's Mental Health: Findings from a 3-Year Panel of Welfare Recipients. Social Science \& Medicine, 61(9), 1971-1982.

Heflin, C. M., \& Ziliak, J. P. (2008). Food Insufficiency, Food Stamp Participation, and Mental Health. Social Science Quarterly, 89(3), 706-727.

Kessler, R. C., Andrews, G., Mroczek, D., Ustun, B., \& Wittchen, H. U. (1998). The World Health Organization Composite International Diagnostic Interview Short-Form (CIDI-SF). International Journal of Methods in Psychiatric Research, 7(4), 171-185.

Layard, R. (2013). Mental Health: The New Frontier for Labour Economics. IZA Journal of Labor Policy, 2(1), 1-16.

Lyons, A. C., \& Yilmazer, T. (2005). Health and Financial Strain: Evidence from the Survey of Consumer Finances. Southern Economic Journal, 71(4), 873-890.

Marcotte, D. E., \& Wilcox-Gok, V. (2003). Estimating Earning Losses Due to Mental Illness: A Quantile Regression Approach. Journal of Mental Health Policy and Economics, 6(3), 123-134.

Marcotte, D., Wilcox-Gok, V., \& Patrick Redmon, D. (2000). The Labor Market Effects of Mental Illness - The Case of Affective Disorders. Research in Human Capital and Development, 13, 181-210.

Nelson, R. E., \& Kim, J. (2011). The Impact of Mental Illness on the Risk of Employment Termination. The Journal of Mental Health Policy and Economics, 14(1), 39-52.

Noonan, K., Reichman, N.E., \& Corman H. (2005). New Fathers' Labor Supply: Does Child Health Matter? Social Science Quarterly, 86(5), 1399-1417 \& 19. 
Nord, M., Andrews, M. \& Carlson, S. (2004) Household Food Security in the United States, 2003. US Department of Agriculture, Economic Research Service. Research Report No. 42. Accessed on 2/12/14 from: http://www.ers.usda.gov/publications/fanrr-foodassistance-nutrition-research-program/fanrr42.aspx\#.UvvB04XEkkA

Ojeda, V. D., Frank, R. G., McGuire, T. G., \& Gilmer, T. P. (2010). Mental Illness, Nativity, Gender and Labor Supply. Health Economics, 19(4), 396-421.

O'Hara, M.W., \& Swain, A.M. (1996). Rates and Risk of Postpartum Depression: A Meta Analysis. International Review of Psychiatry, 8, 37-54.

Pratt, L.A., \& Brody, D.J. (2014). Depression in the United States Household Population, 20092012. NCHS Data Brief 172.

Princeton University. (2012). Fragile Families and Child Wellbeing Study: Core scales documentation. Accessed on 1/3/12 from: http://www.fragilefamilies.princeton.edu/documentation/core/scales/ff_1yr_scales.pdf

Radloff, L.S. (1977). The CES-D Scale: A Self-Report Depression Scale for Research in the General Population. Applied Psychological Measurement, 1(3), 385-401.

Rose, D. (1999). Economic Determinants and Dietary Consequences of Food Insecurity in the United States. The Journal of Nutrition, 129, 517s-520s.

Rosen, H., \& Wu, S. (2004). Portfolio Choice and Health Status. Journal of Financial Economics, 72, 457-484.

Siefert, K., Bowman, P. J., Heflin, C. M., Danziger, S., \& Williams, D. R. (2000). Social and Environmental Predictors of Maternal Depression in Current and Recent Welfare Recipients. American Journal of Orthopsychiatry, 70(4), 510-522.

Singer, L.T., Salvator, A., Guo, S., Collin, M., Lilien, L., \& Baley, J. (1999). Maternal Psychological Distress and Parenting Stress After the Birth of a Very Low-Birth-Weight Infant. Journal of the American Medical Association, 218(9), 799-805.

Smith, J. P. (1999). Healthy Bodies and Thick Wallets: The Dual Relation Between Health and Economic Status. Journal of Economic Perspectives, 13(2), 145-166.

Snow, K., Derecho, A., Wheeless, S., Lennon, J., Rosen, J., Rogers, J., Kinsey, S., Morgan, K., \& Einaudi, P. (2009). Early Childhood Longitudinal Study, Birth Cohort (ECLS-B), Kindergarten 2006 and 2007 Data File User's Manual (2010-010). Washington, DC: National Center for Education Statistics, Institute of Education Sciences, U.S. Department of Education.

Tefft, N. (2012). Mental Health and Employment: The SAD story. Economics and Human Biology, 10(3), 242-255.

Vliegen, N., Casalin, S., \& Luyten, P. (2014). The Course of Postpartum Depression: A Review of Longitudinal Studies. Harvard Review of Psychiatry, 22(1), 1-22.

Wu, S. (2003). The Effects of Health Events on the Economic Status of Married Couples. Journal of Human Resources, 38(1), 219-230. 
Food insecurity (4 years)

$\begin{array}{ccc}\text { Sample A } & \text { Sample B } & \text { Sample C } \\ (\mathrm{N}=\mathbf{8 1 5 0}) & \begin{array}{c}\mathrm{N}=\mathbf{9 , 1 0 0} \\ \text { mothers, 24,700 } \\ \text { observations })\end{array} & \\ & & \\ & & \end{array}$

Food insecurity-children

.070

.069

Food insecurity-household

.120

.120

Food insecurity (2 years)

Food insecurity—children

.041

.043

.039

Food insecurity-household

.086

.088

.083

Food insecurity (9 months)

Food insecurity — children

.048

Food insecurity-household

.115

Maternal depression (4 years; CES-D)

Severe depression

.074

Moderate or severe depression

.198

Maternal depression (2 years; CIDI-SF)

Severe depression

.075

.077

Moderate or severe depression

.103

.104

Maternal depression (9 months; CES-D)

Severe depression

.067

.068

Moderate or severe depression

.175

.177

Maternal characteristics at birth

Age in years, mean (s.d.)

27.9

(6.31)

27.6

27.6

Non-Hispanic white

.512

(6.34)

.499

(6.29)

.528

Non-Hispanic black

.156

.167

.159 
Hispanic

Foreign born

$<$ high school graduate

High school graduate

Any college

Marital birth

Cohabiting partner

Medicaid birth

Employed during year prior to the birth

Lived with both parents at age 16

Prenatal physical health condition

.316

.598
.158

.130

.046

.229 .203

.177

.301

.522

.686

.186

.329

.320

.721

.731

.585

.584

.081

.081

\section{Other family member characteristics ( 9 months)}

Maternal grandmother had history of

.066

.064

.066

depressive symptoms

Child's father < high school graduate

.200

.203

.187

Child's father $=$ high school graduate

.310

.317

.490
.319

.493

\section{Time-varying characteristics (9 months)}

Mother < high school graduate

.160

Mother $=$ high school graduate

.299

Mother has any college

Married

.676 
Cohabiting partner

Number of children in household, mean (s.d.)

Number of adults in household, mean (s.d.)

Mother employed full-time

Mother employed part-time

Household income (\$, divided by 10,000)

Mother lives in urban area

Mother lives in urban cluster

Mother lives in non-urban area

Mother-excellent, very good, or good health

\section{Time-varying characteristics ( 2 years)}

Mother $<$ high school graduate $\quad .151$

Mother $=$ high school graduate

Mother has any college

Married

Cohabiting partner .126

Number of children in household, mean (s.d.)

Number of adults in household, mean (s.d.)

Mother employed full-time

Mother employed part-time

Household income (\$, divided by 10,000 )

Mother lives in urban area 
Mother lives in non-urban area

Mother-excellent, very good, or good health

\section{Time-varying characteristics (4 years)}

Mother < high school graduate $\quad .132$

Mother $=$ high school graduate $\quad .295$

Mother has any college $\quad .573$

$\begin{array}{ll}\text { Married } & .705\end{array}$

$\begin{array}{ll}\text { Cohabiting partner } & .107\end{array}$

Number of children in household, mean (s.d.) 2.51

Number of adults in household, mean (s.d.)

Mother employed full-time

Mother employed part-time $\quad .196$

Household income (\$, divided by 10,000) 6.11

Mother lives in urban area $\quad .691$

Mother lives in urban cluster $\quad .125$

Mother lives in non-urban area $\quad .184$

Mother — excellent, very good, or good health $\quad .906$

\section{Identifiers (used in 2-stage models)}

Multiple birth

Infant health condition

.099

\section{Program participation (4 years)}

SNAP

WIC 
SSI

TANF

\section{Program participation ( 2 years)}

SNAP

TANF

\section{Program participation (9 months)}

WIC

Notes: Figures are proportions unless indicated otherwise. Sample A = sample used for models of maternal depression at 2 years on food insecurity at 4 years. Sample B = sample used for fixed effects models; includes observations at 9 months, 2 years, and 4 years. Sample $C=$ sample used for models of depression at 9 months on food insecurity at 2 years. For each column, figures are provided for variables that are included in models using that sample and shaded cells indicate variables used as outcomes. However, maternal characteristics at 9 months and 9-month "other family member" characteristics are presented for Sample B even though they are not included in those models, in order to allow the reader to compare compositional characteristics across samples. No program participation variables are included in models of food insecurity; program participation is an alternative outcome. Figures are unweighted. All sample sizes are rounded to the nearest 50 as required by the National Center for Education Statistics to protect subject confidentiality. "Baseline" refers to "at the time of or before" the birth of the focal child. s.d. = Standard Deviation. CES-D = Center for Epidemiological Studies Depression Scale. CIDI-SF = Composite International Diagnostic Interview Short Form. SNAP = Supplemental Nutrition Assistance Program. WIC = Supplemental Nutrition Program for Women, Infants, and Children; SSI = Supplemental Security Income [not available at 9 months; means are for sample of mothers who were interviewed at 2 and 4 years]. TANF $=$ Temporary Assistance to Needy Families. 
Table 2: Estimated Effects of Maternal Depression at 2 Years on Food Insecurity at 4 Years, Using Alternative Model Specifications and Measures of Maternal Depression and Food Insecurity (N = 8,150; Sample A)

\begin{tabular}{|c|c|c|c|c|c|}
\hline & $\begin{array}{c}\text { (1) } \\
\text { Probit } \\
\text { Coefficient } \\
\text { (SE) } \\
{[\mathrm{ME}]}\end{array}$ & $\begin{array}{c}(\mathbf{2}) \\
\text { Probit } \\
\text { Coefficient } \\
\text { (SE) } \\
{[\mathrm{ME}]}\end{array}$ & $\begin{array}{c}(\mathbf{3}) \\
\text { Probit } \\
\text { Coefficient } \\
\text { (SE) } \\
{[\mathrm{ME}]}\end{array}$ & $\begin{array}{c}(\mathbf{4}) \\
\text { Probit } \\
\text { Coefficient } \\
\text { (SE) } \\
{[\mathrm{ME}]}\end{array}$ & $\begin{array}{c}(\mathbf{5}) \\
\text { Probit } \\
\text { Coefficient } \\
\text { (SE) } \\
{[\mathrm{ME}]}\end{array}$ \\
\hline \multicolumn{6}{|c|}{ Severe Maternal Depression (at 2 years) } \\
\hline $\begin{array}{l}\text { Food Insecurity- } \\
\text { Child }\end{array}$ & $\begin{array}{c}0.400 * * * \\
(0.068) \\
{[0.068]}\end{array}$ & $\begin{array}{c}0.257 * * * \\
(0.077) \\
{[0.026]}\end{array}$ & $\begin{array}{c}0.236 * * * \\
(0.077) \\
{[0.023]}\end{array}$ & $\begin{array}{c}0.214 * * * \\
(0.080) \\
{[0.020]}\end{array}$ & $\begin{array}{c}0.168 * * \\
(0.080) \\
{[0.016]}\end{array}$ \\
\hline $\begin{array}{l}\text { Food Insecurity- } \\
\text { Household }\end{array}$ & $\begin{array}{c}0.394 * * * \\
(0.061) \\
{[0.094]}\end{array}$ & $\begin{array}{c}0.227 * * * \\
(0.069) \\
{[0.035]}\end{array}$ & $\begin{array}{c}0.214 * * * \\
(0.069) \\
{[0.033]}\end{array}$ & $\begin{array}{c}0.151^{* *} \\
(0.072) \\
{[0.022]}\end{array}$ & $\begin{array}{c}0.094 \\
(0.074) \\
{[0.013]}\end{array}$ \\
\hline \multicolumn{6}{|c|}{ Moderate or Severe Maternal Depression (at 2 years) } \\
\hline $\begin{array}{l}\text { Food Insecurity- } \\
\text { Child }\end{array}$ & $\begin{array}{c}0.431 * * * \\
(0.059) \\
{[0.073]}\end{array}$ & $\begin{array}{c}0.298 * * * \\
(0.067) \\
{[0.031]}\end{array}$ & $\begin{array}{c}0.282 * * * \\
(0.068) \\
{[0.028]}\end{array}$ & $\begin{array}{c}0.261 * * * \\
(0.069) \\
{[0.025]}\end{array}$ & $\begin{array}{c}0.221 * * * \\
(0.070) \\
{[0.021]}\end{array}$ \\
\hline $\begin{array}{l}\text { Food Insecurity- } \\
\text { Household }\end{array}$ & $\begin{array}{c}0.468 * * * \\
(0.052) \\
{[0.113]}\end{array}$ & $\begin{array}{c}0.315 * * * \\
(0.059) \\
{[0.051]}\end{array}$ & $\begin{array}{c}0.306 * * * \\
(0.060) \\
{[0.048]}\end{array}$ & $\begin{array}{c}0.245 * * * \\
(0.061) \\
{[0.037]}\end{array}$ & $\begin{array}{c}0.205^{* * *} \\
(0.063) \\
{[0.031]}\end{array}$ \\
\hline
\end{tabular}

Notes: $* * * \mathrm{p}<0.01 ; * * \mathrm{p}<0.05 ; * \mathrm{p}<0.10 . \mathrm{SE}=$ Standard Error. ME $=$ Marginal Effect. Model 1 includes no covariates. Model 2 includes all maternal characteristics at birth, 9-month other family characteristics, and 2-year time-varying characteristics for which means are shown in the first column of Table 1 (Sample A). Model 3 is the same as Model 2 but also includes indicators for the mother's state of residence at 9 months. Model 4 is same as Model 3 but also includes food insecurity at 9 months (using the measure of food insecurity that corresponds to the outcome). Model 5 is the same as Model 3 but also includes food insecurity at 2 years (using the measure of food insecurity that corresponds to the outcome). Estimates are unweighted. All sample sizes are rounded to the nearest 50 as required by the National Center for Education Statistics to protect subject confidentiality. 
Table 3: Linear Fixed Effects Estimates of the Effects of Maternal Depression and TimeVarying Covariates on Food Insecurity, Using Alternative Measures of Maternal Depression and Food Insecurity ( $N=9,100$ mothers, 24,700 observations; Sample B)

\begin{tabular}{|c|c|c|c|c|}
\hline & $\begin{array}{c}\text { Food } \\
\text { Insecurity } \\
\text { Child } \\
\text { (1) }\end{array}$ & $\begin{array}{c}\text { Food } \\
\text { Insecurity } \\
\text {-Household } \\
\text { (2) }\end{array}$ & $\begin{array}{c}\text { Food } \\
\text { Insecurity } \\
\text { Child } \\
\text { (3) }\end{array}$ & $\begin{array}{c}\text { Food } \\
\text { Insecurity } \\
\text {-Household } \\
\text { (4) }\end{array}$ \\
\hline & \multicolumn{2}{|c|}{ Severe Depression } & \multicolumn{2}{|c|}{ Moderate or Severe Depression } \\
\hline & $\begin{array}{c}\text { Coefficient } \\
\text { (SE) }\end{array}$ & $\begin{array}{c}\text { Coefficient } \\
\text { (SE) }\end{array}$ & $\begin{array}{c}\text { Coefficient } \\
\text { (SE) }\end{array}$ & $\begin{array}{l}\text { Coefficient } \\
\text { (SE) }\end{array}$ \\
\hline Maternal depression & $\begin{array}{c}0.042 * * * \\
(0.010)\end{array}$ & $\begin{array}{l}0.075 * * * \\
(0.012)\end{array}$ & $\begin{array}{c}0.039 * * * \\
(0.006)\end{array}$ & $\begin{array}{c}0.072 * * * \\
(0.008)\end{array}$ \\
\hline High School Graduate & $\begin{array}{c}0.006 \\
(0.013)\end{array}$ & $\begin{array}{c}0.005 \\
(0.016)\end{array}$ & $\begin{array}{c}0.006 \\
(0.012)\end{array}$ & $\begin{array}{c}0.005 \\
(0.016)\end{array}$ \\
\hline Any College & $\begin{array}{l}-0.003 \\
(0.014)\end{array}$ & $\begin{array}{l}-0.007 \\
(0.018)\end{array}$ & $\begin{array}{l}-0.004 \\
(0.014)\end{array}$ & $\begin{array}{l}-0.008 \\
(0.018)\end{array}$ \\
\hline Married & $\begin{array}{l}-0.017 \\
(0.012)\end{array}$ & $\begin{array}{l}-0.010 \\
(0.015)\end{array}$ & $\begin{array}{l}-0.016 \\
(0.012)\end{array}$ & $\begin{array}{l}-0.009 \\
(0.015)\end{array}$ \\
\hline Cohabiting partner & $\begin{array}{c}-0.027 * * \\
(0.011)\end{array}$ & $\begin{array}{c}-0.033 * * \\
(0.014)\end{array}$ & $\begin{array}{c}-0.027 * * \\
(0.011)\end{array}$ & $\begin{array}{c}-0.033 * * \\
(0.014)\end{array}$ \\
\hline $\begin{array}{l}\text { Number of children in } \\
\text { household }\end{array}$ & $\begin{array}{l}0.012 * * * \\
(0.003)\end{array}$ & $\begin{array}{c}0.003 \\
(0.005)\end{array}$ & $\begin{array}{c}0.012 * * * \\
(0.003)\end{array}$ & $\begin{array}{c}0.003 \\
(0.005)\end{array}$ \\
\hline $\begin{array}{l}\text { Number of adults in } \\
\text { household }\end{array}$ & $\begin{array}{c}-0.011 * * * \\
(0.004)\end{array}$ & $\begin{array}{c}-0.016 * * * \\
(0.005)\end{array}$ & $\begin{array}{c}-0.011 * * * \\
(0.004)\end{array}$ & $\begin{array}{c}-0.015 * * * \\
(0.005)\end{array}$ \\
\hline Employed full time & $\begin{array}{c}0.003 \\
(0.006)\end{array}$ & $\begin{array}{l}-0.003 \\
(0.007)\end{array}$ & $\begin{array}{c}0.003 \\
(0.006)\end{array}$ & $\begin{array}{l}-0.002 \\
(0.007)\end{array}$ \\
\hline Employed part time & $\begin{array}{c}0.000 \\
(0.006)\end{array}$ & $\begin{array}{l}-0.000 \\
(0.007)\end{array}$ & $\begin{array}{c}0.000 \\
(0.006)\end{array}$ & $\begin{array}{l}-0.000 \\
(0.007)\end{array}$ \\
\hline Household income & $\begin{array}{c}-0.004 * * * \\
(0.001)\end{array}$ & $\begin{array}{c}-0.008 * * * \\
(0.001)\end{array}$ & $\begin{array}{c}-0.004 * * * \\
(0.001)\end{array}$ & $\begin{array}{c}-0.008 * * * \\
(0.001)\end{array}$ \\
\hline Lives in urban area & $\begin{array}{l}-0.014 \\
(0.010)\end{array}$ & $\begin{array}{l}-0.012 \\
(0.013)\end{array}$ & $\begin{array}{l}-0.013 \\
(0.010)\end{array}$ & $\begin{array}{l}-0.010 \\
(0.013)\end{array}$ \\
\hline Lives in urban cluster & $\begin{array}{l}-0.016 \\
(0.015)\end{array}$ & $\begin{array}{l}-0.027 \\
(0.018)\end{array}$ & $\begin{array}{l}-0.015 \\
(0.015)\end{array}$ & $\begin{array}{l}-0.026 \\
(0.018)\end{array}$ \\
\hline $\begin{array}{l}\text { Excellent, very good, } \\
\text { or very good heath }\end{array}$ & $\begin{array}{l}-0.011 \\
(0.010)\end{array}$ & $\begin{array}{l}-0.016 \\
(0.012)\end{array}$ & $\begin{array}{l}-0.011 \\
(0.010)\end{array}$ & $\begin{array}{l}-0.015 \\
(0.012)\end{array}$ \\
\hline
\end{tabular}

Notes: *** $\mathrm{p}<0.01 ; * * \mathrm{p}<0.05 ; * \mathrm{p}<0.10 . \mathrm{SE}=$ Standard Error. Estimates are unweighted,.

Models include observations from 9 months, 2 years, and 4 years, with all analysis variables 
measured contemporaneously at the given observation. All sample sizes are rounded to the nearest 50 as required by the National Center for Education Statistics to protect subject confidentiality. 
Table 4: Estimated Effects of Maternal Depression at 9 Months on Food Insecurity at 2 Years, Using Alternative Model Specifications and Measures of Maternal Depression and Food Insecurity ( $=7,800$; Sample C)

\begin{tabular}{cccc}
$(\mathbf{1})$ & $(\mathbf{2})$ & $(\mathbf{3})$ & $\mathbf{( 4 )}$ \\
\hline Probit & Probit & Probit & Probit \\
Coefficient & Coefficient & Coefficient & Coefficient \\
(SE) & (SE) & (SE) & (SE) \\
{$[\mathrm{ME}]$} & {$[\mathrm{ME}]$} & {$[\mathrm{ME}]$} & {$[\mathrm{ME}]$} \\
\hline
\end{tabular}

\begin{tabular}{|c|c|c|c|c|}
\hline \multicolumn{5}{|c|}{ Severe Maternal Depression (at 9 months) } \\
\hline $\begin{array}{l}\text { Food Insecurity- } \\
\text { Child }\end{array}$ & $\begin{array}{c}0.677 * * * \\
(0.076) \\
{[0.090]}\end{array}$ & $\begin{array}{c}0.540 * * * \\
(0.079) \\
{[0.047]}\end{array}$ & $\begin{array}{c}0.516 * * * \\
(0.080) \\
{[0.034]}\end{array}$ & $\begin{array}{r}0.461 * * * \\
(0.084) \\
{[0.029]}\end{array}$ \\
\hline $\begin{array}{l}\text { Food Insecurity- } \\
\text { Household }\end{array}$ & $\begin{array}{c}0.667 * * * \\
(0.065) \\
{[0.143]}\end{array}$ & $\begin{array}{c}0.515^{* * * *} \\
(0.069) \\
{[0.083]}\end{array}$ & $\begin{array}{c}0.487 * * * \\
(0.070) \\
{[0.063]}\end{array}$ & $\begin{array}{c}0.368^{* * * *} \\
(0.074) \\
{[0.042]}\end{array}$ \\
\hline \multicolumn{5}{|c|}{ Moderate or Severe Maternal Depression (at 9 months) } \\
\hline $\begin{array}{l}\text { Food Insecurity_- } \\
\text { Child }\end{array}$ & $\begin{array}{c}0.519 * * * \\
(0.058) \\
{[0.056]}\end{array}$ & $\begin{array}{c}0.410 * * * \\
(0.063) \\
{[0.029]}\end{array}$ & $\begin{array}{c}0.396^{* * *} \\
(0.065) \\
{[0.021]}\end{array}$ & $\begin{array}{r}0.369 * * * \\
(0.067) \\
{[0.019]}\end{array}$ \\
\hline $\begin{array}{l}\text { Food Insecurity- } \\
\text { Household }\end{array}$ & $\begin{array}{c}0.518 * * * \\
(0.047) \\
{[0.096]}\end{array}$ & $\begin{array}{c}0.368 * * * \\
(0.051) \\
{[0.051]}\end{array}$ & $\begin{array}{c}0.344 * * * \\
(0.052) \\
{[0.037]}\end{array}$ & $\begin{array}{c}0.252^{* * * *} \\
(0.055) \\
{[0.025]}\end{array}$ \\
\hline
\end{tabular}

Notes: $* * * \mathrm{p}<0.01 ; * * \mathrm{p}<0.05 ; * \mathrm{p}<0.10 . \mathrm{SE}=$ Standard Error. ME $=$ Marginal Effect. Model 1 includes no covariates. Model 2 includes all maternal characteristics at birth and 9-month other family characteristics in the third column of Table 1 (Sample C), and state of residence indicators from the 9-month survey. Model 3 is the same as Model 2 but also includes 9-month characteristics classified as time-varying for which means are shown in the third column of Table 1 (Sample C). Model 4 is the same as Model 3 but also includes 9 month food insecurity that corresponds to the outcome. Estimates are unweighted. All sample sizes are rounded to the nearest 50 as required by the National Center for Education Statistics to protect subject confidentiality. 
Table 5: Estimated Effects of Maternal Depression on Program Participation

\begin{tabular}{|c|c|c|c|c|c|}
\hline & SNAP & WIC & Medicaid & SSI & TANF \\
\hline Sample A & $\begin{array}{c}\text { Probit } \\
\text { Coefficient } \\
\text { (SE) } \\
{[\mathrm{ME}]}\end{array}$ & $\begin{array}{c}\text { Probit } \\
\text { Coefficient } \\
\text { (SE) } \\
{[\mathrm{ME}]}\end{array}$ & $\begin{array}{c}\text { Probit } \\
\text { Coefficient } \\
\text { (SE) } \\
{[\mathrm{ME}]}\end{array}$ & $\begin{array}{c}\text { Probit } \\
\text { Coefficient } \\
\text { (SE) } \\
{[\mathrm{ME}]}\end{array}$ & $\begin{array}{c}\text { Probit } \\
\text { Coefficient } \\
\text { (SE) } \\
{[\mathrm{ME}]}\end{array}$ \\
\hline $\begin{array}{l}\text { Severe } \\
\text { Depression }\end{array}$ & $\begin{array}{c}0.087 \\
(0.076) \\
{[0.019]}\end{array}$ & $\begin{array}{c}-0.020 \\
(0.067) \\
{[-0.006]}\end{array}$ & $\begin{array}{c}-0.048 \\
(0.074) \\
{[-0.015]}\end{array}$ & $\begin{array}{c}0.115 \\
(0.084) \\
{[0.009]}\end{array}$ & $\begin{array}{l}0.160^{*} \\
(0.085) \\
{[0.009]}\end{array}$ \\
\hline $\begin{array}{l}\text { Moderate or } \\
\text { Severe } \\
\text { Depression }\end{array}$ & $\begin{array}{c}0.129 * * \\
(0.065) \\
{[0.028]}\end{array}$ & $\begin{array}{c}0.025 \\
(0.058) \\
{[0.007]}\end{array}$ & $\begin{array}{c}-0.023 \\
(0.062) \\
{[-0.007]}\end{array}$ & $\begin{array}{c}0.152 * * \\
(0.073) \\
{[0.012]}\end{array}$ & $\begin{array}{l}0.153 * * \\
(0.076) \\
{[0.008]}\end{array}$ \\
\hline
\end{tabular}

Sample B (fixed effects)

\begin{tabular}{|c|c|c|c|c|c|}
\hline & $\begin{array}{c}\text { Coefficient } \\
\text { (SE) }\end{array}$ & $\begin{array}{c}\text { Coefficient } \\
\text { (SE) }\end{array}$ & $\begin{array}{c}\text { Coefficient } \\
\text { (SE) }\end{array}$ & $\begin{array}{l}\text { Coefficient } \\
\text { (SE) }\end{array}$ & $\begin{array}{l}\text { Coefficient } \\
\text { (SE) }\end{array}$ \\
\hline $\begin{array}{l}\text { Severe } \\
\text { Depression }\end{array}$ & $\begin{array}{c}0.025^{* *} \\
(0.011)\end{array}$ & $\begin{array}{c}0.005 \\
(0.012)\end{array}$ & $\begin{array}{l}0.020 * \\
(0.011)\end{array}$ & $\begin{array}{c}0.014 \\
(0.010)\end{array}$ & $\begin{array}{l}-0.010 \\
(0.010)\end{array}$ \\
\hline $\begin{array}{l}\text { Moderate or } \\
\text { Severe } \\
\text { Depression }\end{array}$ & $\begin{array}{c}0.028 * * * \\
(0.007)\end{array}$ & $\begin{array}{c}-0.003 \\
(0.009)\end{array}$ & $\begin{array}{c}0.025 * * * \\
(0.008)\end{array}$ & $\begin{array}{c}0.029 * * * \\
(0.008)\end{array}$ & $\begin{array}{c}0.012 \\
(0.007)\end{array}$ \\
\hline
\end{tabular}

Notes: $* * * \mathrm{p}<0.01 ; * * \mathrm{p}<0.05 ; * \mathrm{p}<0.10 . \mathrm{SE}=$ Standard Error. ME $=$ Marginal Effect. "Sample A" models estimate effects of maternal depression at 2 years on program participation at 4 years, controlling for 2-year participation in the same program and the same set of covariates as in Model 3 of Table 2. "Sample B" (fixed effects) models, other than those for SSI, include observations at 9 months, 2 years, and 4 years and control for all time-varying covariates in Table 1; the models for SSI include observations (and control for time-varying covariates) at 2 and 4 years but not 9 months, because the 9-month survey did not ask about SSI. $\mathrm{N}=8,150$ for Sample A models. N = 9,100 mothers and 24,700 observations for Sample B models for SNAP, WIC, Medicaid, and TANF. N = 7,750 mothers and 15,450 observations for Sample B models for SSI. Estimates are unweighted. All sample sizes are rounded to the nearest 50 as required by the National Center for Education Statistics to protect subject confidentiality. 
Appendix Table 1: Core Food Security Module Questions

\begin{tabular}{|c|c|c|}
\hline \multicolumn{2}{|r|}{ (bolded questions pertain to children) } & $\begin{array}{l}\text { How often in } \\
\text { the last } 12 \\
\text { months? }\end{array}$ \\
\hline \multirow{3}{*}{1} & \multirow{3}{*}{$\begin{array}{l}\text { (I/We) worried whether (my/our) food would run out before } \\
\text { (I/we) got money to buy more. }\end{array}$} & Often true \\
\hline & & Sometimes true \\
\hline & & Never true \\
\hline \multirow{3}{*}{2} & \multirow{3}{*}{$\begin{array}{l}\text { The food that (I/we) bought just didn't last, and (I/we) didn't have } \\
\text { money to get more. }\end{array}$} & Often true \\
\hline & & Sometimes true \\
\hline & & Never true \\
\hline \multirow{3}{*}{3} & \multirow{3}{*}{ (I/we) couldn't afford to eat balanced meals. } & Often true \\
\hline & & Sometimes true \\
\hline & & Never true \\
\hline \multirow{3}{*}{4} & \multirow{3}{*}{$\begin{array}{l}\text { (I/we) relied on only a few kinds of low-cost food to feed } \\
\text { (my/our child/the children) because (I was/we were) running } \\
\text { out of money to buy food. }\end{array}$} & Often true \\
\hline & & Sometimes true \\
\hline & & Never true \\
\hline \multirow[b]{2}{*}{5} & \multirow{2}{*}{$\begin{array}{l}\text { Did (you/you or other adults in your household) ever cut } \\
\text { the size of your meals or skip meals because there wasn't } \\
\text { enough money for food? }\end{array}$} & Yes \\
\hline & & No \\
\hline \multirow{3}{*}{6} & \multirow{3}{*}{$\begin{array}{l}\text { (I/we) couldn't feed (my/our child/the children) a balanced } \\
\text { meal, because (I/we) couldn't afford that. }\end{array}$} & Often true \\
\hline & & Sometimes true \\
\hline & & Never true \\
\hline \multirow{2}{*}{7} & \multirow{2}{*}{$\begin{array}{l}\text { Did you ever eat less than you felt you should because } \\
\text { there wasn't enough money for food? }\end{array}$} & Yes \\
\hline & & No \\
\hline \multirow{3}{*}{8} & \multirow{3}{*}{$\begin{array}{l}\text { How often did (you/you or other adults in your household) } \\
\text { cut the size of your meals or skip meals because there } \\
\text { wasn't enough money for food? }\end{array}$} & Only 1-2 months \\
\hline & & $\begin{array}{l}\text { Some but not } \\
\text { every month }\end{array}$ \\
\hline & & $\begin{array}{l}\text { Almost every } \\
\text { month }\end{array}$ \\
\hline \multirow{3}{*}{9} & \multirow{3}{*}{$\begin{array}{l}\text { (My/Our child was/The children were) not eating enough } \\
\text { because (I/we) just couldn't afford enough food. }\end{array}$} & Often true \\
\hline & & Sometimes true \\
\hline & & Never true \\
\hline \multirow[b]{2}{*}{10} & \multirow{2}{*}{$\begin{array}{l}\text { Were you ever hungry but didn't eat because you couldn't afford } \\
\text { enough food? }\end{array}$} & Yes \\
\hline & & No \\
\hline \multirow[b]{2}{*}{11} & \multirow{2}{*}{$\begin{array}{l}\text { Did you lose weight because you didn't have enough money for } \\
\text { food? }\end{array}$} & Yes \\
\hline & & No \\
\hline \multirow[b]{2}{*}{12} & \multirow{2}{*}{$\begin{array}{l}\text { Did you ever cut the size of (your child's/any of the } \\
\text { children's) meals because there wasn't enough money }\end{array}$} & Yes \\
\hline & & No \\
\hline \multirow[b]{2}{*}{13} & \multirow{2}{*}{$\begin{array}{l}\text { Did (you/you or other adults in your household) ever not eat } \\
\text { for a whole day because there wasn't enough money for }\end{array}$} & Yes \\
\hline & & No \\
\hline \multirow[b]{2}{*}{14} & \multirow{2}{*}{$\begin{array}{l}\text { (Was your child/Were the children) ever hungry } \\
\text { but you just couldn't afford more food? }\end{array}$} & Yes \\
\hline & & No \\
\hline
\end{tabular}




\begin{tabular}{|c|c|c|}
\hline \multirow{3}{*}{15} & \multirow{3}{*}{$\begin{array}{l}\text { How often did (you/you or other adults in your household) } \\
\text { not eat for a whole day because there wasn't enough } \\
\text { money for food? }\end{array}$} & Only 1-2 months \\
\hline & & $\begin{array}{l}\text { Some but not } \\
\text { every month }\end{array}$ \\
\hline & & $\begin{array}{l}\text { Almost every } \\
\text { month }\end{array}$ \\
\hline \multirow[b]{2}{*}{16} & \multirow{2}{*}{$\begin{array}{l}\text { Did (your child/any of the children) ever skip a meal } \\
\text { because there wasn't enough money for food? }\end{array}$} & Yes \\
\hline & & No \\
\hline \multirow{3}{*}{17} & \multirow{3}{*}{$\begin{array}{l}\text { How often did (your child/any of the children) skip a meal } \\
\text { because there wasn't enough money for food? }\end{array}$} & Only 1-2 months \\
\hline & & $\begin{array}{l}\text { Some but not } \\
\text { every month }\end{array}$ \\
\hline & & $\begin{array}{l}\text { Almost every } \\
\text { month }\end{array}$ \\
\hline \multirow[b]{2}{*}{18} & \multirow{2}{*}{$\begin{array}{l}\text { Did (your child/any of the children) ever not eat for a } \\
\text { whole day because there wasn't enough money for food? }\end{array}$} & Yes \\
\hline & & No \\
\hline
\end{tabular}

Source: U.S. Department of Agriculture (http://www.ers.usda.gov/topics/food-nutritionassistance/food-security-in-the-us/measurement.aspx\#.U_szlWMfI7E). Questions are embedded in the ECLS-B National 9 Month and 2-Year Parent Questionnaires and the Preschool National Study: Parent Interview. 
Appendix Table 2: Estimated Effects of Severe Maternal Depression at 2 Years and Covariates on Child and Household Food Insecurity at 4 Years (N = 8,150; Sample A)

\begin{tabular}{cc}
$\begin{array}{c}\text { Food Insecurity- } \\
\text { Child }\end{array}$ & $\begin{array}{c}\text { Food Insecurity- } \\
\text { Household }\end{array}$ \\
\hline Probit Coefficient & Probit Coefficient \\
(SE) & $(\mathrm{SE})$ \\
{$[\mathrm{ME}]$} & {$[\mathrm{ME}]$} \\
\hline
\end{tabular}

Maternal depression

$0.214 * * *$

$0.151 * *$

$(0.080)$

$(0.072)$

[0.020]

[0.022]

Mother's age

$0.008 *$

0.006

(0.004)

(0.004)

[0.001]

[0.001]

Non-Hispanic black

0.123

$-0.006$

(0.076)

(0.066)

[0.011]

$[-0.001]$

Hispanic

$0.166^{*}$

$-0.000$

(0.086)

$(0.075)$

[0.015]

[-0.000]

Asian or Pacific Islander

$0.199 *$

$-0.024$

(0.105)

(0.096)

[0.018]

[-0.003]

American Indian

$-0.044$

0.010

(0.118)

(0.101)

$[-0.003]$

[0.001]

Foreign born

0.120

0.060

(0.081)

(0.072)

[0.010]

[0.008]

Medicaid birth

$0.196 * * *$

(0.061)

$0.203^{* * *}$

[0.017]

(0.052)

[0.028]

Mother lived with both parents at age 16

$-0.086 *$

$-0.075^{*}$

(0.051)

(0.044)

[-0.007]

[-0.010]

Maternal grandmother had history of

$0.263 * * *$

$0.144 *$

depressive symptoms

(0.086)

(0.078)

[0.026]

[0.021]

Father high school graduate

0.011

$-0.045$

(0.059)

(0.052)

[0.001]

[-0.006] 


\begin{tabular}{|c|c|c|}
\hline Father some college or more & $\begin{array}{c}-0.253 * * * \\
(0.076) \\
{[-0.021]}\end{array}$ & $\begin{array}{c}-0.310 * * * \\
(0.065) \\
{[-0.040]}\end{array}$ \\
\hline Mother high school graduate (2years) & $\begin{array}{c}-0.106 * \\
(0.063) \\
{[-0.008]}\end{array}$ & $\begin{array}{c}-0.084 \\
(0.056) \\
{[-0.011]}\end{array}$ \\
\hline Mother some college or more (2years) & $\begin{array}{c}-0.128 * \\
(0.077) \\
{[-0.011]}\end{array}$ & $\begin{array}{c}-0.153 * * \\
(0.067) \\
{[-0.020]}\end{array}$ \\
\hline Married (2 years) & $\begin{array}{c}-0.204 * * * \\
(0.070) \\
{[-0.018]}\end{array}$ & $\begin{array}{c}-0.148 * * \\
(0.062) \\
{[-0.020]}\end{array}$ \\
\hline Cohabiting partner (2 years) & $\begin{array}{c}-0.132 * \\
(0.077) \\
{[-0.010]}\end{array}$ & $\begin{array}{c}-0.156 * * \\
(0.069) \\
{[-0.019]}\end{array}$ \\
\hline Number of children in household (2 years) & $\begin{array}{c}0.068 * * * \\
(0.019) \\
{[0.006]}\end{array}$ & $\begin{array}{c}0.077 * * * \\
(0.017) \\
{[0.010]}\end{array}$ \\
\hline Number of adults in household ( 2 years) & $\begin{array}{c}0.001 \\
(0.029) \\
{[0.000]}\end{array}$ & $\begin{array}{c}0.034 \\
(0.025) \\
{[0.004]}\end{array}$ \\
\hline Employed full-time (2 years) & $\begin{array}{c}0.019 \\
(0.056) \\
{[0.002]}\end{array}$ & $\begin{array}{c}0.014 \\
(0.049) \\
{[0.002]}\end{array}$ \\
\hline Employed part-time (2 years) & $\begin{array}{c}0.102 \\
(0.067) \\
{[0.009]}\end{array}$ & $\begin{array}{c}0.077 \\
(0.059) \\
{[0.010]}\end{array}$ \\
\hline Income ( 2 years) & $\begin{array}{c}-0.085 * * * \\
(0.013) \\
{[-0.007]}\end{array}$ & $\begin{array}{c}-0.095 * * * \\
(0.012) \\
{[-0.012]}\end{array}$ \\
\hline Lived in urban area (2 years) & $\begin{array}{l}0.125 * \\
(0.074) \\
{[0.010]}\end{array}$ & $\begin{array}{c}0.007 \\
(0.063) \\
{[0.001]}\end{array}$ \\
\hline Lived in urban cluster ( 2 years) & $\begin{array}{c}0.212 * * \\
(0.087) \\
{[0.020]}\end{array}$ & $\begin{array}{c}0.052 \\
(0.074) \\
{[0.007]}\end{array}$ \\
\hline Excellent, very good, or good health (2 years) & $\begin{array}{c}-0.172 * * \\
(0.073) \\
{[-0.016]}\end{array}$ & $\begin{array}{c}-0.191 * * * \\
(0.064) \\
{[-0.028]}\end{array}$ \\
\hline $\begin{array}{l}\text { Food insecurity at } 2 \text { years (measure } \\
\text { corresponding to outcome) }\end{array}$ & $\begin{array}{c}0.693 * * * \\
(0.074) \\
{[0.095]}\end{array}$ & $\begin{array}{c}0.788 * * * \\
(0.051) \\
{[0.156]}\end{array}$ \\
\hline
\end{tabular}


Notes: Estimates are from Model 4 in Table 2 (top panel). *** $\mathrm{p}<0.01$; ** $\mathrm{p}<0.05 ; * \mathrm{p}<0.10$. $\mathrm{SE}=$ Standard Error. $\mathrm{ME}=$ Marginal Effect. Estimates are unweighted. All sample sizes are rounded to the nearest 50 as required by the National Center for Education Statistics to protect subject confidentiality. Estimates for state indicators are not shown. 
Appendix Table 3: Effects of Severe Maternal Depression at 9 Months and Covariates on Child and Household Food Insecurity at 2 Years (N = 7,800; Sample C)

\begin{tabular}{|c|c|c|}
\hline & $\begin{array}{c}\begin{array}{c}\text { Food Insecurity- } \\
\text { Child }\end{array} \\
\text { Probit Coefficient } \\
(\mathrm{SE}) \\
{[\mathrm{ME}]} \\
\end{array}$ & $\begin{array}{c}\begin{array}{c}\text { Food Insecurity- } \\
\text { Household }\end{array} \\
\text { Probit Coefficient } \\
(\mathrm{SE}) \\
{[\mathrm{ME}]} \\
\end{array}$ \\
\hline Maternal depression & $\begin{array}{c}0.461 * * * \\
(0.084) \\
{[0.029]}\end{array}$ & $\begin{array}{c}0.368 * * * \\
(0.074) \\
{[0.042]}\end{array}$ \\
\hline Mother's age & $\begin{array}{l}0.011^{*} \\
(0.006) \\
{[0.000]}\end{array}$ & $\begin{array}{c}-0.001 \\
(0.005) \\
{[-0.000]}\end{array}$ \\
\hline Non-Hispanic black & $\begin{array}{l}0.162 * \\
(0.093) \\
{[0.007]}\end{array}$ & $\begin{array}{c}0.068 \\
(0.075) \\
{[0.006]}\end{array}$ \\
\hline Hispanic & $\begin{array}{c}0.247 * * \\
(0.107) \\
{[0.012]}\end{array}$ & $\begin{array}{c}-0.050 \\
(0.087) \\
{[-0.004]}\end{array}$ \\
\hline Asian or Pacific Islander & $\begin{array}{c}-0.030 \\
(0.150) \\
{[-0.001]}\end{array}$ & $\begin{array}{c}-0.189 \\
(0.115) \\
{[-0.015]}\end{array}$ \\
\hline American Indian & $\begin{array}{c}0.194 \\
(0.123) \\
{[0.010]}\end{array}$ & $\begin{array}{c}0.130 \\
(0.104) \\
{[0.013]}\end{array}$ \\
\hline Foreign born & $\begin{array}{c}0.034 \\
(0.104) \\
{[0.001]}\end{array}$ & $\begin{array}{c}0.077 \\
(0.085) \\
{[0.007]}\end{array}$ \\
\hline High school graduate & $\begin{array}{c}-0.006 \\
(0.077) \\
{[-0.000]}\end{array}$ & $\begin{array}{c}0.065 \\
(0.064) \\
{[0.006]}\end{array}$ \\
\hline Any college & $\begin{array}{c}-0.120 \\
(0.097) \\
{[-0.005]}\end{array}$ & $\begin{array}{c}0.122 \\
(0.077) \\
{[0.011]}\end{array}$ \\
\hline Marital birth & $\begin{array}{c}0.288 * * * \\
(0.104) \\
{[0.011]}\end{array}$ & $\begin{array}{c}0.173 * * \\
(0.083) \\
{[0.014]}\end{array}$ \\
\hline Cohabiting partner & $\begin{array}{c}0.217 * * \\
(0.096) \\
{[0.010]}\end{array}$ & $\begin{array}{l}0.153^{*} \\
(0.078) \\
{[0.015]}\end{array}$ \\
\hline
\end{tabular}




\begin{tabular}{|c|c|c|}
\hline Medicaid birth & $\begin{array}{l}0.170 * * \\
(0.074) \\
{[0.007]}\end{array}$ & $\begin{array}{c}0.281 * * * \\
(0.060) \\
{[0.027]}\end{array}$ \\
\hline $\begin{array}{l}\text { Employed during year } \\
\text { prior to the birth }\end{array}$ & $\begin{array}{c}0.059 \\
(0.066) \\
{[0.002]}\end{array}$ & $\begin{array}{l}0.022 \\
(0.054) \\
{[0.002]}\end{array}$ \\
\hline $\begin{array}{l}\text { Mother lived with both } \\
\text { parents at age } 16\end{array}$ & $\begin{array}{c}-0.144 * * \\
(0.063) \\
{[-0.006]}\end{array}$ & $\begin{array}{c}-0.135 * * * \\
(0.052) \\
{[-0.012]}\end{array}$ \\
\hline $\begin{array}{l}\text { Prenatal physical health } \\
\text { condition }\end{array}$ & $\begin{array}{c}0.091 \\
(0.103) \\
{[0.004]}\end{array}$ & $\begin{array}{l}0.143 * \\
(0.083) \\
{[0.014]}\end{array}$ \\
\hline $\begin{array}{l}\text { Maternal grandmother had } \\
\text { history of depressive } \\
\text { symptoms }\end{array}$ & $\begin{array}{l}0.191 * \\
(0.105) \\
{[0.009]}\end{array}$ & $\begin{array}{l}0.184 * * \\
(0.084) \\
{[0.019]}\end{array}$ \\
\hline $\begin{array}{l}\text { Father high school } \\
\text { graduate }\end{array}$ & $\begin{array}{l}-0.075 \\
(0.073) \\
{[-0.003]}\end{array}$ & $\begin{array}{c}-0.151 * * \\
(0.060) \\
{[-0.013]}\end{array}$ \\
\hline $\begin{array}{l}\text { Father some college or } \\
\text { more }\end{array}$ & $\begin{array}{c}-0.234 * * \\
(0.094) \\
{[-0.010]}\end{array}$ & $\begin{array}{c}-0.292 * * * \\
(0.073) \\
{[-0.026]}\end{array}$ \\
\hline $\begin{array}{l}\text { Number of children in } \\
\text { household ( } 9 \text { months) }\end{array}$ & $\begin{array}{c}0.087 * * * \\
(0.020) \\
{[0.004]}\end{array}$ & $\begin{array}{c}0.061 * * * \\
(0.018) \\
{[0.005]}\end{array}$ \\
\hline $\begin{array}{l}\text { Number of adults in } \\
\text { household ( } 9 \text { months) }\end{array}$ & $\begin{array}{l}0.004 \\
(0.037) \\
{[0.000]}\end{array}$ & $\begin{array}{l}-0.030 \\
(0.030) \\
{[-0.003]}\end{array}$ \\
\hline $\begin{array}{l}\text { Household income ( } 9 \\
\text { months) }\end{array}$ & $\begin{array}{c}-0.088 * * * \\
(0.021) \\
{[-0.004]}\end{array}$ & $\begin{array}{c}-0.089 * * * \\
(0.015) \\
{[-0.008]}\end{array}$ \\
\hline $\begin{array}{l}\text { Lived in urban area } \\
\text { (9 months) }\end{array}$ & $\begin{array}{l}0.124 \\
(0.088) \\
{[0.005]}\end{array}$ & $\begin{array}{l}0.049 \\
(0.069) \\
{[0.004]}\end{array}$ \\
\hline $\begin{array}{l}\text { Lived in urban cluster } \\
\text { (9 months) }\end{array}$ & $\begin{array}{l}0.230 * * \\
(0.103) \\
{[0.011]}\end{array}$ & $\begin{array}{l}0.178 * * \\
(0.082) \\
{[0.018]}\end{array}$ \\
\hline $\begin{array}{l}\text { Food insecurity at } 9 \\
\text { months (measure } \\
\text { corresponding to outcome) }\end{array}$ & $\begin{array}{c}0.763 * * * \\
(0.087) \\
{[0.065]}\end{array}$ & $\begin{array}{c}0.885 * * * \\
(0.057) \\
{[0.137]}\end{array}$ \\
\hline
\end{tabular}

Notes: Estimates are from Model 4 in Table 4 (top panel). *** $\mathrm{p}<0.01 ; * * \mathrm{p}<0.05 ; * \mathrm{p}<0.10$. $\mathrm{SE}=$ Standard Error. $\mathrm{ME}=$ Marginal Effect. Estimates are unweighted. All sample sizes are 
rounded to the nearest 50 as required by the National Center for Education Statistics to protect subject confidentiality. 
Appendix Table 4: Bivariate Probit Estimates of Effects of Severe Maternal Depression at 9 Months on Food Insecurity at 2 Years ( $=7,800$; Sample $C)$

\begin{tabular}{|c|c|c|c|c|}
\hline & $\begin{array}{c}\text { Maternal } \\
\text { Depression }\end{array}$ & $\begin{array}{c}\text { Food } \\
\text { Insecurity- } \\
\text { Child }\end{array}$ & $\begin{array}{c}\text { Maternal } \\
\text { Depression }\end{array}$ & $\begin{array}{c}\text { Food } \\
\text { Insecurity- } \\
\text { Household }\end{array}$ \\
\hline \multirow[b]{2}{*}{ Maternal depression } & $\begin{array}{l}\text { Coefficient } \\
\text { (SE) }\end{array}$ & $\begin{array}{c}\text { Coefficient } \\
\text { (SE) } \\
{[\mathrm{ME}]}\end{array}$ & $\begin{array}{c}\text { Coefficient } \\
\text { (SE) }\end{array}$ & $\begin{array}{c}\text { Coefficient } \\
(\mathrm{SE}) \\
{[\mathrm{ME}]}\end{array}$ \\
\hline & & $\begin{array}{c}1.133 \\
(0.797) \\
{[0.132]}\end{array}$ & & $\begin{array}{c}-0.128 \\
(0.649) \\
{[-0.010]}\end{array}$ \\
\hline Mother's age & $\begin{array}{c}0.008 \\
(0.005)\end{array}$ & $\begin{array}{l}0.011 * \\
(0.006) \\
{[0.000]}\end{array}$ & $\begin{array}{c}0.005 \\
(0.005)\end{array}$ & $\begin{array}{c}-0.001 \\
(0.005) \\
{[-0.000]}\end{array}$ \\
\hline Non-Hispanic black & $\begin{array}{c}0.083 \\
(0.076)\end{array}$ & $\begin{array}{c}0.151 \\
(0.092) \\
{[0.007]}\end{array}$ & $\begin{array}{c}0.079 \\
(0.076)\end{array}$ & $\begin{array}{c}0.069 \\
(0.075) \\
{[0.006]}\end{array}$ \\
\hline Hispanic & $\begin{array}{c}0.029 \\
(0.085)\end{array}$ & $\begin{array}{c}0.238 * * \\
(0.106) \\
{[0.012]}\end{array}$ & $\begin{array}{c}0.019 \\
(0.086)\end{array}$ & $\begin{array}{c}-0.053 \\
(0.086) \\
{[-0.005]}\end{array}$ \\
\hline Asian or Pacific Islander & $\begin{array}{c}0.223 * * \\
(0.093)\end{array}$ & $\begin{array}{c}-0.066 \\
(0.148) \\
{[-0.003]}\end{array}$ & $\begin{array}{c}0.223 * * \\
(0.093)\end{array}$ & $\begin{array}{c}-0.183 \\
(0.117) \\
{[-0.015]}\end{array}$ \\
\hline American Indian & $\begin{array}{l}-0.063 \\
(0.115)\end{array}$ & $\begin{array}{c}0.193 \\
(0.121) \\
{[0.010]}\end{array}$ & $\begin{array}{l}-0.065 \\
(0.114)\end{array}$ & $\begin{array}{c}0.111 \\
(0.104) \\
{[0.011]}\end{array}$ \\
\hline Foreign born & $\begin{array}{c}-0.182 * * \\
(0.079)\end{array}$ & $\begin{array}{c}0.044 \\
(0.103) \\
{[0.002]}\end{array}$ & $\begin{array}{c}-0.187 * * \\
(0.079)\end{array}$ & $\begin{array}{c}0.060 \\
(0.088) \\
{[0.006]}\end{array}$ \\
\hline High school graduate & $\begin{array}{l}-0.051 \\
(0.065)\end{array}$ & $\begin{array}{c}-0.001 \\
(0.076) \\
{[-0.000]}\end{array}$ & $\begin{array}{l}-0.029 \\
(0.066)\end{array}$ & $\begin{array}{c}0.061 \\
(0.064) \\
{[0.006]}\end{array}$ \\
\hline Any college & $\begin{array}{l}-0.111 \\
(0.077)\end{array}$ & $\begin{array}{c}-0.109 \\
(0.097) \\
{[-0.005]}\end{array}$ & $\begin{array}{l}-0.089 \\
(0.077)\end{array}$ & $\begin{array}{c}0.116 \\
(0.078) \\
{[0.010]}\end{array}$ \\
\hline Marital birth & $\begin{array}{c}-0.260 * * * \\
(0.077)\end{array}$ & $\begin{array}{c}0.316 * * * \\
(0.105) \\
{[0.012]}\end{array}$ & $\begin{array}{c}-0.264 * * * \\
(0.077)\end{array}$ & $\begin{array}{c}0.144 \\
(0.095) \\
{[0.012]}\end{array}$ \\
\hline Cohabiting & $\begin{array}{c}-0.173 * * \\
(0.076)\end{array}$ & $\begin{array}{c}0.235 * * \\
(0.096) \\
{[0.012]}\end{array}$ & $\begin{array}{c}-0.179 * * \\
(0.075)\end{array}$ & $\begin{array}{c}0.130 \\
(0.086) \\
{[0.013]}\end{array}$ \\
\hline
\end{tabular}




\begin{tabular}{|c|c|c|c|c|}
\hline Medicaid birth & $\begin{array}{l}0.209 * * * \\
(0.061)\end{array}$ & $\begin{array}{l}0.152 * * \\
(0.076) \\
{[0.007]}\end{array}$ & $\begin{array}{l}0.178 * * * \\
(0.061)\end{array}$ & $\begin{array}{c}0.294 * * * \\
(0.061) \\
{[0.029]}\end{array}$ \\
\hline $\begin{array}{l}\text { Employed during year prior } \\
\text { to the birth }\end{array}$ & $\begin{array}{l}-0.013 \\
(0.053)\end{array}$ & $\begin{array}{c}0.057 \\
(0.065) \\
{[0.002]}\end{array}$ & $\begin{array}{l}-0.015 \\
(0.053)\end{array}$ & $\begin{array}{l}0.023 \\
(0.054) \\
{[0.002]}\end{array}$ \\
\hline $\begin{array}{l}\text { Mother lived with both } \\
\text { parents at age } 16\end{array}$ & $\begin{array}{l}-0.092 * \\
(0.049)\end{array}$ & $\begin{array}{c}-0.133 * * \\
(0.064) \\
{[-0.006]}\end{array}$ & $\begin{array}{l}-0.082 * \\
(0.049)\end{array}$ & $\begin{array}{c}-0.140 * * * \\
(0.052) \\
{[-0.013]}\end{array}$ \\
\hline $\begin{array}{l}\text { Prenatal physical health } \\
\text { condition }\end{array}$ & $\begin{array}{l}-0.072 \\
(0.087)\end{array}$ & $\begin{array}{l}0.092 \\
(0.102) \\
{[0.004]}\end{array}$ & $\begin{array}{l}-0.082 \\
(0.087)\end{array}$ & $\begin{array}{l}0.133 \\
(0.084) \\
{[0.013]}\end{array}$ \\
\hline $\begin{array}{l}\text { Maternal grandmother had } \\
\text { history of depressive } \\
\text { symptoms }\end{array}$ & $\begin{array}{l}0.491 * * * \\
(0.076)\end{array}$ & $\begin{array}{l}0.125 \\
(0.120) \\
{[0.006]}\end{array}$ & $\begin{array}{l}0.467 * * * \\
(0.078)\end{array}$ & $\begin{array}{l}0.228 * * \\
(0.107) \\
{[0.024]}\end{array}$ \\
\hline Father high school graduate & $\begin{array}{c}0.016 \\
(0.063)\end{array}$ & $\begin{array}{l}-0.078 \\
(0.072) \\
{[-0.003]}\end{array}$ & $\begin{array}{c}0.025 \\
(0.063)\end{array}$ & $\begin{array}{c}-0.145 * * \\
(0.061) \\
{[-0.013]}\end{array}$ \\
\hline Father some college or more & $\begin{array}{l}-0.110 \\
(0.074)\end{array}$ & $\begin{array}{c}-0.227 * * \\
(0.093) \\
{[-0.010]}\end{array}$ & $\begin{array}{l}-0.085 \\
(0.074)\end{array}$ & $\begin{array}{c}-0.293 * * * \\
(0.072) \\
{[-0.026]}\end{array}$ \\
\hline $\begin{array}{l}\text { Number of children in } \\
\text { household }\end{array}$ & $\begin{array}{c}0.018 \\
(0.020)\end{array}$ & $\begin{array}{c}0.082 * * * \\
(0.022) \\
{[0.004]}\end{array}$ & $\begin{array}{c}0.025 \\
(0.021)\end{array}$ & $\begin{array}{c}0.067 * * * \\
(0.019) \\
{[0.006]}\end{array}$ \\
\hline $\begin{array}{l}\text { Number of adults in } \\
\text { household }\end{array}$ & $\begin{array}{c}0.014 \\
(0.029)\end{array}$ & $\begin{array}{c}0.004 \\
(0.036) \\
{[0.000]}\end{array}$ & $\begin{array}{c}0.021 \\
(0.029)\end{array}$ & $\begin{array}{l}-0.030 \\
(0.030) \\
{[-0.003]}\end{array}$ \\
\hline Income & $\begin{array}{l}-0.015 * \\
(0.008)\end{array}$ & $\begin{array}{c}-0.086 * * * \\
(0.021) \\
{[-0.004]}\end{array}$ & $\begin{array}{l}-0.008 \\
(0.008)\end{array}$ & $\begin{array}{c}-0.088 * * * \\
(0.015) \\
{[-0.008]}\end{array}$ \\
\hline Urban area & $\begin{array}{l}-0.019 \\
(0.068)\end{array}$ & $\begin{array}{l}0.122 \\
(0.087) \\
{[0.005]}\end{array}$ & $\begin{array}{l}-0.018 \\
(0.068)\end{array}$ & $\begin{array}{l}0.045 \\
(0.069) \\
{[0.004]}\end{array}$ \\
\hline Urban cluster & $\begin{array}{l}-0.189 * * \\
(0.086)\end{array}$ & $\begin{array}{l}0.241 * * \\
(0.102) \\
{[0.013]}\end{array}$ & $\begin{array}{c}-0.184 * * \\
(0.087)\end{array}$ & $\begin{array}{l}0.157 * \\
(0.088) \\
{[0.016]}\end{array}$ \\
\hline $\begin{array}{l}\text { Food insecurity at } 9 \text { months } \\
\text { (measure corresponding to } \\
\text { outcome) }\end{array}$ & $\begin{array}{l}0.415 * * * \\
(0.087)\end{array}$ & $\begin{array}{c}0.691 * * * \\
(0.129) \\
{[0.058]}\end{array}$ & $\begin{array}{c}0.489 * * * \\
(0.061)\end{array}$ & $\begin{array}{c}0.925 * * * \\
(0.068) \\
{[0.149]}\end{array}$ \\
\hline
\end{tabular}




\section{Identifiers}

Multiple birth

$0.138 * *$

$0.116^{*}$

(0.062)

(0.062)

Infant health condition

0.077

(0.072)

0.066

$(0.072)$

Rho

$-.331$

.262

Test Results (p-values)

Wald Test of rho $=0$

.402 .

.460

Chi-square joint significance

.040

.097

test of identifiers

Exclusion tests:

Multiple birth

Infant health condition

Notes: $* * * \mathrm{p}<0.01 ; * * \mathrm{p}<0.05 ; * \mathrm{p}<0.10 . \mathrm{SE}=$ Standard Error. ME = Marginal Effect. Estimates are unweighted. All sample sizes are rounded to the nearest 50 as required by the National Center for Education Statistics to protect subject confidentiality. All models include state indicators (estimates not shown). The total number of children in the household at 9 months, which was included in the other Sample C models, was not included in these models because multiple birth is directly related to the number of infants in the household; instead, we included the "number of other children in household," which equals the total number of children in the household minus the focal child and his/her multiple birth siblings (if any) 
Appendix Table 5: Estimated Effects of Severe Maternal Depression at 2 Years and Covariates on Program Participation at 4 Years ( $=8,150$; Sample A)

\begin{tabular}{|c|c|c|c|c|c|}
\hline & SNAP & WIC & Medicaid & SSI & TANF \\
\hline & $\begin{array}{c}\text { Probit } \\
\text { Coefficient } \\
\text { (SE) } \\
{[\mathrm{ME}]}\end{array}$ & $\begin{array}{c}\text { Probit } \\
\text { Coefficient } \\
\text { (SE) } \\
{[\mathrm{ME}]}\end{array}$ & $\begin{array}{c}\text { Probit } \\
\text { Coefficient } \\
\text { (SE) } \\
{[\mathrm{ME}]}\end{array}$ & $\begin{array}{c}\text { Probit } \\
\text { Coefficient } \\
\text { (SE) } \\
{[\mathrm{ME}]}\end{array}$ & $\begin{array}{c}\text { Probit } \\
\text { Coefficient } \\
\text { (SE) } \\
{[\mathrm{ME}]}\end{array}$ \\
\hline $\begin{array}{l}\text { Maternal } \\
\text { depression }\end{array}$ & $\begin{array}{c}0.087 \\
(0.076) \\
{[0.019]}\end{array}$ & $\begin{array}{c}-0.02 \\
(0.067) \\
{[-0.006]}\end{array}$ & $\begin{array}{c}-0.048 \\
(0.074) \\
{[-0.015]}\end{array}$ & $\begin{array}{c}0.115 \\
(0.084) \\
{[0.009]}\end{array}$ & $\begin{array}{l}0.160 * \\
(0.085) \\
{[0.009]}\end{array}$ \\
\hline Mother's age & $\begin{array}{c}-0.020 * * * \\
(0.004) \\
{[-0.004]}\end{array}$ & $\begin{array}{c}-0.008 * * \\
(0.003) \\
{[-0.002]}\end{array}$ & $\begin{array}{c}-0.020 * * * \\
(0.004) \\
{[-0.006]}\end{array}$ & $\begin{array}{c}0.020 * * * \\
(0.005) \\
{[0.001]}\end{array}$ & $\begin{array}{c}-0.009 * \\
(0.005) \\
{[-0.000]}\end{array}$ \\
\hline $\begin{array}{l}\text { Non-Hispanic } \\
\text { black }\end{array}$ & $\begin{array}{c}0.323 * * * \\
(0.065) \\
{[0.075]}\end{array}$ & $\begin{array}{c}0.180 * * * \\
(0.058) \\
{[0.056]}\end{array}$ & $\begin{array}{c}0.243 * * * \\
(0.060) \\
{[0.080]}\end{array}$ & $\begin{array}{c}0.049 \\
(0.078) \\
{[0.004]}\end{array}$ & $\begin{array}{c}0.328 * * * \\
(0.079) \\
{[0.020]}\end{array}$ \\
\hline Hispanic & $\begin{array}{c}-0.142 * \\
(0.076) \\
{[-0.027]}\end{array}$ & $\begin{array}{c}0.312 * * * \\
(0.066) \\
{[0.099]}\end{array}$ & $\begin{array}{c}0.173 * * \\
(0.069) \\
{[0.056]}\end{array}$ & $\begin{array}{c}-0.073 \\
(0.101) \\
{[-0.005]}\end{array}$ & $\begin{array}{c}-0.073 \\
(0.094) \\
{[-0.003]}\end{array}$ \\
\hline $\begin{array}{l}\text { Asian or Pacific } \\
\text { Islander }\end{array}$ & $\begin{array}{c}0.015 \\
(0.097) \\
{[0.003]}\end{array}$ & $\begin{array}{c}-0.127 \\
(0.080) \\
{[-0.036]}\end{array}$ & $\begin{array}{c}0.016 \\
(0.082) \\
{[0.005]}\end{array}$ & $\begin{array}{c}0.003 \\
(0.132) \\
{[0.000]}\end{array}$ & $\begin{array}{l}0.224 * \\
(0.120) \\
{[0.013]}\end{array}$ \\
\hline American Indian & $\begin{array}{c}-0.050 \\
(0.096) \\
{[-0.010]}\end{array}$ & $\begin{array}{c}0.265 * * * \\
(0.085) \\
{[0.085]}\end{array}$ & $\begin{array}{c}0.116 \\
(0.093) \\
{[0.038]}\end{array}$ & $\begin{array}{c}-0.065 \\
(0.133) \\
{[-0.004]}\end{array}$ & $\begin{array}{c}0.304 * * * \\
(0.104) \\
{[0.020]}\end{array}$ \\
\hline Foreign born & $\begin{array}{c}-0.337 * * * \\
(0.072) \\
{[-0.062]}\end{array}$ & $\begin{array}{l}0.114 * \\
(0.061) \\
{[0.034]}\end{array}$ & $\begin{array}{c}-0.046 \\
(0.064) \\
{[-0.014]}\end{array}$ & $\begin{array}{c}-0.362 * * * \\
(0.101) \\
{[-0.022]}\end{array}$ & $\begin{array}{c}-0.542 * * * \\
(0.095) \\
{[-0.020]}\end{array}$ \\
\hline Medicaid birth & $\begin{array}{c}0.289 * * * \\
(0.049) \\
{[0.063]}\end{array}$ & $\begin{array}{c}0.136 * * * \\
(0.046) \\
{[0.041]}\end{array}$ & $\begin{array}{c}0.352 * * * \\
(0.046) \\
{[0.115]}\end{array}$ & $\begin{array}{c}0.230 * * * \\
(0.065) \\
{[0.018]}\end{array}$ & $\begin{array}{c}0.201 * * * \\
(0.062) \\
{[0.010]}\end{array}$ \\
\hline $\begin{array}{l}\text { Mother lived with } \\
\text { both parents at age } \\
16\end{array}$ & $\begin{array}{c}-0.088 * * \\
(0.042) \\
{[-0.018]}\end{array}$ & $\begin{array}{c}0.022 \\
(0.039) \\
{[0.006]}\end{array}$ & $\begin{array}{c}-0.007 \\
(0.039) \\
{[-0.002]}\end{array}$ & $\begin{array}{c}-0.083 \\
(0.055) \\
{[-0.006]}\end{array}$ & $\begin{array}{l}-0.105 * \\
(0.055) \\
{[-0.005]}\end{array}$ \\
\hline $\begin{array}{l}\text { Father high school } \\
\text { graduate }\end{array}$ & $\begin{array}{c}-0.191 * * * \\
(0.053) \\
{[-0.037]}\end{array}$ & $\begin{array}{c}-0.035 \\
(0.049) \\
{[-0.010]}\end{array}$ & $\begin{array}{c}-0.131 * * \\
(0.052) \\
{[-0.040]}\end{array}$ & $\begin{array}{c}0.026 \\
(0.066) \\
{[0.002]}\end{array}$ & $\begin{array}{l}-0.106 * \\
(0.061) \\
{[-0.005]}\end{array}$ \\
\hline
\end{tabular}




\begin{tabular}{|c|c|c|c|c|c|}
\hline $\begin{array}{l}\text { Father some } \\
\text { college or more }\end{array}$ & $\begin{array}{c}-0.409 * * * \\
(0.063) \\
{[-0.083]}\end{array}$ & $\begin{array}{c}-0.147 * * * \\
(0.056) \\
{[-0.043]}\end{array}$ & $\begin{array}{c}-0.313 * * * \\
(0.058) \\
{[-0.097]}\end{array}$ & $\begin{array}{c}-0.057 \\
(0.078) \\
{[-0.004]}\end{array}$ & $\begin{array}{c}-0.261 * * * \\
(0.083) \\
{[-0.013]}\end{array}$ \\
\hline $\begin{array}{l}\text { Mother high } \\
\text { school graduate ( } 2 \\
\text { years) }\end{array}$ & $\begin{array}{c}-0.065 \\
(0.059) \\
{[-0.013]}\end{array}$ & $\begin{array}{c}-0.036 \\
(0.054) \\
{[-0.011]}\end{array}$ & $\begin{array}{l}0.096 * \\
(0.058) \\
{[0.030]}\end{array}$ & $\begin{array}{c}-0.012 \\
(0.072) \\
{[-0.001]}\end{array}$ & $\begin{array}{c}-0.096 \\
(0.067) \\
{[-0.004]}\end{array}$ \\
\hline $\begin{array}{l}\text { Mother some } \\
\text { college or more ( } 2 \\
\text { years) }\end{array}$ & $\begin{array}{c}-0.268 * * * \\
(0.067) \\
{[-0.055]}\end{array}$ & $\begin{array}{c}-0.194 * * * \\
(0.061) \\
{[-0.058]}\end{array}$ & $\begin{array}{c}-0.066 \\
(0.064) \\
{[-0.021]}\end{array}$ & $\begin{array}{c}-0.044 \\
(0.084) \\
{[-0.003]}\end{array}$ & $\begin{array}{c}-0.305 * * * \\
(0.085) \\
{[-0.015]}\end{array}$ \\
\hline $\begin{array}{l}\text { Married } \\
(2 \text { years })\end{array}$ & $\begin{array}{c}-0.315 * * * \\
(0.059) \\
{[-0.069]}\end{array}$ & $\begin{array}{l}-0.003 \\
(0.055) \\
{[-0.001]}\end{array}$ & $\begin{array}{c}-0.290 * * * \\
(0.056) \\
{[-0.094]}\end{array}$ & $\begin{array}{c}-0.423 * * * \\
(0.075) \\
{[-0.037]}\end{array}$ & $\begin{array}{c}-0.395 * * * \\
(0.075) \\
{[-0.023]}\end{array}$ \\
\hline $\begin{array}{l}\text { Cohabiting partner } \\
\text { ( } 2 \text { years) }\end{array}$ & $\begin{array}{c}-0.083 \\
(0.068) \\
{[-0.016]}\end{array}$ & $\begin{array}{c}0.092 \\
(0.065) \\
{[0.028]}\end{array}$ & $\begin{array}{c}0.029 \\
(0.067) \\
{[0.009]}\end{array}$ & $\begin{array}{c}-0.242 * * * \\
(0.083) \\
{[-0.015]}\end{array}$ & $\begin{array}{l}-0.005 \\
(0.074) \\
{[-0.000]}\end{array}$ \\
\hline $\begin{array}{l}\text { Number of } \\
\text { children in } \\
\text { household } \\
\text { ( } 2 \text { years) }\end{array}$ & $\begin{array}{c}0.090 * * * \\
(0.017) \\
{[0.018]}\end{array}$ & $\begin{array}{c}0.049 * * * \\
(0.016) \\
{[0.015]}\end{array}$ & $\begin{array}{c}0.089 * * * \\
(0.017) \\
{[0.028]}\end{array}$ & $\begin{array}{c}0.069 * * * \\
(0.021) \\
{[0.005]}\end{array}$ & $\begin{array}{c}0.065 * * * \\
(0.021) \\
{[0.003]}\end{array}$ \\
\hline $\begin{array}{l}\text { Number of adults } \\
\text { in household } \\
(2 \text { years })\end{array}$ & $\begin{array}{c}0.036 \\
(0.026) \\
{[0.007]}\end{array}$ & $\begin{array}{l}-0.010 \\
(0.024) \\
{[-0.003]}\end{array}$ & $\begin{array}{c}0.019 \\
(0.026) \\
{[0.006]}\end{array}$ & $\begin{array}{c}0.015 \\
(0.033) \\
{[0.001]}\end{array}$ & $\begin{array}{c}-0.006 \\
(0.031) \\
{[-0.000]}\end{array}$ \\
\hline $\begin{array}{l}\text { Employed full time } \\
\text { ( } 2 \text { years) }\end{array}$ & $\begin{array}{c}-0.208 * * * \\
(0.049) \\
{[-0.041]}\end{array}$ & $\begin{array}{c}-0.093 * * \\
(0.043) \\
{[-0.027]}\end{array}$ & $\begin{array}{c}-0.295 * * * \\
(0.045) \\
{[-0.089]}\end{array}$ & $\begin{array}{c}-0.208 * * * \\
(0.062) \\
{[-0.014]}\end{array}$ & $\begin{array}{c}-0.197 * * * \\
(0.064) \\
{[-0.009]}\end{array}$ \\
\hline $\begin{array}{l}\text { Employed part } \\
\text { time } \\
\text { ( } 2 \text { years })\end{array}$ & $\begin{array}{c}-0.159 * * * \\
(0.058) \\
{[-0.031]}\end{array}$ & $\begin{array}{c}0.079 \\
(0.051) \\
{[0.024]}\end{array}$ & $\begin{array}{c}-0.112 * * \\
(0.052) \\
{[-0.034]}\end{array}$ & $\begin{array}{c}-0.188 * * * \\
(0.073) \\
{[-0.012]}\end{array}$ & $\begin{array}{c}-0.241 * * * \\
(0.077) \\
{[-0.010]}\end{array}$ \\
\hline $\begin{array}{l}\text { Household Income } \\
\text { ( } 2 \text { years) }\end{array}$ & $\begin{array}{c}-0.108 * * * \\
(0.013) \\
{[-0.022]}\end{array}$ & $\begin{array}{c}-0.096 * * * \\
(0.009) \\
{[-0.028]}\end{array}$ & $\begin{array}{c}-0.100 * * * \\
(0.010) \\
{[-0.031]}\end{array}$ & $\begin{array}{c}-0.048 * * * \\
(0.011) \\
{[-0.004]}\end{array}$ & $\begin{array}{c}-0.108 * * * \\
(0.023) \\
{[-0.005]}\end{array}$ \\
\hline $\begin{array}{l}\text { Lived in urban } \\
\text { area } \\
\text { ( } 2 \text { years })\end{array}$ & $\begin{array}{l}-0.083 \\
(0.060) \\
{[-0.017]}\end{array}$ & $\begin{array}{c}-0.155 * * * \\
(0.054) \\
{[-0.047]}\end{array}$ & $\begin{array}{l}-0.075 \\
(0.055) \\
{[-0.024]}\end{array}$ & $\begin{array}{c}-0.086 \\
(0.074) \\
{[-0.006]}\end{array}$ & $\begin{array}{c}0.089 \\
(0.076) \\
{[0.004]}\end{array}$ \\
\hline $\begin{array}{l}\text { Lived in urban } \\
\text { cluster ( } 2 \text { years) }\end{array}$ & $\begin{array}{c}0.019 \\
(0.071) \\
{[0.004]}\end{array}$ & $\begin{array}{l}-0.058 \\
(0.066) \\
{[-0.017]}\end{array}$ & $\begin{array}{c}0.017 \\
(0.067) \\
{[0.005]}\end{array}$ & $\begin{array}{c}0.018 \\
(0.088) \\
{[0.001]}\end{array}$ & $\begin{array}{c}-0.006 \\
(0.091) \\
{[-0.000]}\end{array}$ \\
\hline
\end{tabular}




$\begin{array}{lccccc}\begin{array}{l}\text { Excellent, very } \\ \text { good, or good }\end{array} & -0.157 * * & -0.124 * * & -0.137 * * & -0.134 * & -0.170 * * \\ \text { health (2 years) } & (0.068) & (0.061) & (0.067) & (0.078) & (0.073) \\ & {[-0.034]} & {[-0.038]} & {[-0.045]} & {[-0.011]} & {[-0.010]} \\ \text { Corresponding } & 1.138 * * * & 1.265 * * * & 0.960 * * * & 1.762 * * * & 0.962 * * * \\ \text { program } & (0.051) & (0.043) & (0.047) & (0.070) & (0.069) \\ \text { participation at 2 } & {[0.317]} & {[0.392]} & {[0.322]} & {[0.400]} & {[0.106]} \\ \text { years (e.g., SNAP } & & & & \\ \text { at 2 years when } & & & \\ \text { estimating SNAP } \\ \text { at 4 years) }\end{array}$


Appendix Table 6: Fixed Effects Estimates of the Effects of Severe Depression and TimeVarying Covariates on Program Participation $(\mathrm{N}=$ 9,100 mothers, 24,700 observations; Sample B)

\begin{tabular}{cccc} 
SNAP & WIC & Medicaid & TANF \\
\hline Coefficient & Coefficient & Coefficient & Coefficient \\
$(\mathrm{SE})$ & $(\mathrm{SE})$ & $(\mathrm{SE})$ & $(\mathrm{SE})$ \\
\hline
\end{tabular}

Maternal depression

$\begin{array}{cccc}0.025^{* *} & 0.005 & 0.020^{*} & -0.010 \\ (0.011) & (0.012) & (0.011) & (0.010)\end{array}$

High School Graduate

$\begin{array}{cccc}0.058 * * * & 0.003 & 0.009 & 0.017 \\ (0.018) & (0.019) & (0.018) & (0.017)\end{array}$

Any College

$\begin{array}{cccc}0.061^{* * *} & -0.010 & 0.000 & 0.016 \\ (0.021) & (0.023) & (0.020) & (0.019)\end{array}$

Married

$\begin{array}{cccc}-0.094 * * * & -0.080 * * * & -0.058 * * * & -0.047 * * * \\ (0.017) & (0.018) & (0.016) & (0.015)\end{array}$

Cohabiting partner

$\begin{array}{cccc}-0.058 * * * & 0.002 & 0.007 & -0.022 \\ (0.015) & (0.017) & (0.015) & (0.016)\end{array}$

Number of children in household

$\begin{array}{cccc}0.021 * * * & 0.033 * * * & 0.017 * * * & -0.004 \\ (0.005) & (0.005) & (0.005) & (0.005)\end{array}$

Number of adults in household

$\begin{array}{cccc}-0.025 * * * & 0.005 & 0.010 * & 0.002 \\ (0.005) & (0.006) & (0.006) & (0.005)\end{array}$

Employed full time

$$
\begin{array}{cccc}
-0.033 * * * & -0.051 * * * & -0.045 * * * & -0.014 * * \\
(0.008) & (0.010) & (0.009) & (0.007)
\end{array}
$$

Employed part time

$\begin{array}{llll}-0.011 & -0.010 & -0.002 & -0.007 \\ (0.008) & (0.009) & (0.009) & (0.007)\end{array}$

Household income

$$
\begin{array}{cccc}
-0.008 * * * & -0.010 * * * & -0.010 * * * & -0.004 * * * \\
(0.001) & (0.001) & (0.001) & (0.001)
\end{array}
$$

Lives in urban area

$\begin{array}{lccc}-0.028 * & 0.003 & -0.001 & -0.003 \\ (0.015) & (0.016) & (0.015) & (0.012)\end{array}$


Lives in urban cluster

$\begin{array}{cccc}0.007 & 0.030 & 0.008 & 0.014 \\ (0.020) & (0.021) & (0.020) & (0.017)\end{array}$

Excellent, very good, or very good heath

Notes: Models correspond to bottom panel in Table 5. *** $\mathrm{p}<0.01 ; * * \mathrm{p}<0.05 ; * \mathrm{p}<0.10 . \mathrm{SE}=$ Standard Error. Models include observations from 9 months, 2 years, and 4 years, with all analysis variables measured contemporaneously at the given observation. Estimates are unweighted. All sample sizes are rounded to the nearest 50 as required by the National Center for Education Statistics to protect subject confidentiality. 